\title{
THE ROLE OF ENVIRONMENTAL FACTORS IN THE FORMATION OF ZOOPLANKTON IN TRIBUTARIES OF LAKE LADOGA (RUSSIA)
}

\author{
Kurashov, E. A. ${ }^{1,3^{*}}$ - AleshinA, D. G. ${ }^{1}$ - GuSEVA, M. A. ${ }^{1}$ - PETROVA, T. N. ${ }^{1}-$ \\ KRYLOVA, J. V., \\ ${ }^{I}$ Institute of Limnology, Russian Academy of Sciences \\ 9 Sevastyanova street, Saint Petersburg, 196105, Russia \\ ${ }^{2}$ Berg State Researh Institute on Lake and River Fisheries \\ 26 Makarova nab., Saint Petersburg, 199053, Russia \\ ${ }^{3}$ ITMO University \\ 49 Kronverkskiy pr., Saint Petersburg, 197101, Russia \\ *Corresponding author \\ e-mail: evgeny_kurashov@mail.ru; phone:+7-812-387-80-60 \\ (Received $19^{\text {th }}$ Feb 2017; accepted $30^{\text {th }}$ Aug 2017)
}

\begin{abstract}
The role of environmental factors in the formation of zooplankton in tributaries of Lake Ladoga is still poorly investigated. The authors aimed at exploring composition and quantitative patterns of zooplankton development in the major tributaries of Ladoga and assessing the impact of environmental factors and features of river catchment basins on the parameters of zooplankton development. A total of 137 taxa ranking below genus were identified (56 species and subspecies of Rotifera, 57 of Cladocera, 24 of Copepoda). Species composition and patterns of quantitative development cannot be explained by any environmental factors or their combination. It is impossible to determine groups of rivers with similar patterns of zooplankton development basing on the composition and abundances of individual zooplankton species. River clustering based on hydrochemical and hydrological parameters and features of catchment basins provides an opportunity to distinguish groups of similar rivers. Total abundances of copepoda, cladocera, and rotifera in the rivers are closely associated with certain combinations of studied physiographic parameters. Physiographic factors, namely, the catchment basin area, water discharge, and lake percentage on the territory of the catchment basin, are the most important in the level of quantitative development of Copepoda, Rotifera, and Cladocera in tributaries of Lake Ladoga.
\end{abstract}

Keywords: Copepoda, Cladocera, Rotifera, rivers, species composition, physiographic factors

\section{Introduction}

Tributaries of Lake Ladoga greatly influence its water balance, hydrochemical water composition, biocenoses, and general ecological condition. River discharge counts for almost $85 \%$ of water balance input and more than $95 \%$ of chemical balance of the lake (Alekin, 1953). In river ecosystems, zooplankton community is an important structural and functional unit, for exampe, zooplankton organisms are a primary food source for larval and some adult fish (Thorp and Casper, 2003).

Zooplankton of lake tributaries have seldom been studied in comparison with zooplankton of lakes and reservoirs (Thorp and Mantovani, 2005; Turschak et al., 2011). Development of zooplankton in rivers is controlled by a still poorly understood mixture of abiotic and biotic factors varying seasonally and correlated to chemical and physical features of the rivers and physiographic conditions of their drainage basins (Thorp and Casper, 2002; Zhao et al., 2017). 
Planktonic crustaceans and rotifers play a big part in the process of transformation and circulation of organic matter and so participate in river self-purification (Krylov, 2002a; Ejsmont-Karabin et al., 2004).

Contrary to thoroughly studied zooplankton of Lake Ladoga (Andronikova, 1996; Kurashov et al., 1996; Telesh, 1996; Korovchinsky, 2000), the zooplankton of its tributaries has not been properly studied.

Literature contains limited data on zooplankton communities of some rivers of the Northern Ladoga area (Ryzhkov, 1999; Kulikova, 2012; Ryabinkina et al., 2012) and main tributaries (Makartseva, 2004; Kulikova, 2012; Aleshina et al., 2014). These data have been collected with the help of different methods at various times, therefore, the results cannot be properly compared, making it impossible to assess the influence of environmental factors on the communities of crustaceans and rotifers. It is vital to determine the patterns of this influence to provide a better understanding of the processes taking place in river ecosystems and opportunity to model and predict the zooplankton reaction to environmental changes, including those connected with current climate changes (Vadadi-Fülöp et al., 2009).

Previous studies of the Lake Ladoga tributaries have shown that the development of phytoplankton in rivers depends on the supply with nutrients, first of all, phosphorus, and on factors such as the productivity in the source of the river, character and rate of river flow, presence or absence of lakes or widened stretches with retarded water exchange in the course of the river (Trifonova and Pavlova, 2004). The role of environmental factors in the formation of zooplankton in tributaries of Lake Ladoga is still poorly investigated.

In this study, we aimed to explore qualitative composition and quantitative patterns of development of zooplankton in the major tributaries of Lake Ladoga, and to assess the impact of environmental factors and features of river catchment basins on the parameters of zooplankton development.

In the face of constantly increasing anthropogenic load on the Lake Ladoga catchment basin (Kondratyev and Trumbull, 2012), it is important to reveal interactions between environmental factors and the state of biota. In this connection, the results of the current study can be used to develop the strategy for management and preservation of water resources of the Ladoga area rivers.

\section{Materials and Methods}

\section{Study area}

Three major tributaries can be determined within the catchment basin of Lake Ladoga: the Svir, the Volkhov, and the Vuoksa system of lakes and rivers, entering Lake Ladoga in two branches - the northern one, Vuoksa River, and the southern one, Burnaya River. Second-order tributaries are the Pasha, the Oyat, the Syas, and the Olonka rivers. Although the Pasha and the Oyat are tributaries of the Svir, they are considered to be independent lake tributaries, as they enter the Svir near its mouth. There are 20 major water courses entering Ladoga (Table 1), including the Burnaya and the Vuoksa, which actually belong to the same Vuoksa system of lakes and rivers. For our study in 2011-2014 we chose the stations at the lower course of these rivers and at the Neva River head (Fig. 1). 


\section{Material and data analysis}

Our study included 9 periods: May, August, and October 2011, July and October 2012, June and September 2013, May and July 2014. Hydrochemical data were obtained with the help of YSI 6600D multiparameter automatic sonde (YSI Incorporated, USA) directly during the zooplankton sampling within the surface layers or assessed with routine methods at the laboratory (Semenov (ed.), 1977). The following parameters were measured and used for the statistical analyses (abbreviations are given for the variables that were later included in the regression equations): content of aluminium ( $\mathrm{Al}, \mu \mathrm{g} / \mathrm{l})$, copper $(\mathrm{Cu}, \mu \mathrm{g} / \mathrm{l})$, iron $(\mathrm{Fe}, \mu \mathrm{g} / \mathrm{l})$, lead $(\mathrm{Pb}, \mu \mathrm{g} / \mathrm{l})$, zinc $(\mathrm{Zn}$, $\mu \mathrm{g} / \mathrm{l})$, sodium and potassium $(\mathrm{Na}+\mathrm{K}, \mu \mathrm{g} / \mathrm{l})$, manganese $(\mathrm{Mn}, \mu \mathrm{g} / \mathrm{l})$, ions of calcium $\left(\mathrm{Ca}^{2+}, \mu \mathrm{g} / \mathrm{l}\right)$ and magnesium $\left(\mathrm{Mg}^{2+}, \mu \mathrm{g} / \mathrm{l}\right)$, ammonium $\left(\mathrm{NH}_{4}^{+}, \mathrm{mg} / \mathrm{l}\right)$, chlorides $\left(\mathrm{Cl}^{-}\right.$, $\mathrm{mg} / \mathrm{l})$, nitrates $\left(\mathrm{NO}_{3}^{-}, \mathrm{mg} / \mathrm{l}\right)$, sulphates $\left(\mathrm{SO}_{4}{ }^{2-}, \mathrm{mg} / \mathrm{l}\right)$, carbonates $\left(\mathrm{HCO}_{3}^{-}, \mathrm{mg} / \mathrm{l}\right)$, total nitrogen $\left(\mathrm{N}_{\text {tot }}, \mathrm{mg} / \mathrm{l}\right)$ and phosphorus $\left(\mathrm{P}_{\text {tot }}, \mathrm{mg} / \mathrm{l}\right)$, inorganic phosphorus $\left(\mathrm{P}_{\min }, \mathrm{mg} / \mathrm{l}\right)$, total carbon (TOC, mgC/l), biological oxygen demand in 5 days $\left(\mathrm{BOD}_{5}, \mathrm{mgO}_{2} / \mathrm{l}\right)$, chemical oxygen demand $\left(\mathrm{COD}, \mathrm{mgO}_{2} / \mathrm{l}\right)$, hardness of water, content of hydrocarbons (Carb, $\mathrm{mg} / \mathrm{l}$ ), content of oxygen (percent saturation and $\mathrm{mg} / \mathrm{l}$ ), content of total suspended matter, water colour ( $\mathrm{W}_{\text {col }}$, degrees), turbidity (NTU), acidity $(\mathrm{pH})$, specific conductance (Cond, $\mathrm{mS} / \mathrm{cm}$ ), total dissolved solids (TDS, g/l), temperature, content of chlorophyll $(\mathrm{Chl}, \mu \mathrm{g} / \mathrm{l})$ and cyanobacteria abundance (BGA, cells/ml).

Table 1. Characteristics of catchments and the long-term average discharges of the studied rivers (Tarakanova, 1965).

\begin{tabular}{c|c|c|c|c|c|c}
\hline o. & River & $\begin{array}{c}\text { The } \\
\text { catchment } \\
\text { area, km }\end{array}$ & $\begin{array}{c}\text { Lake } \\
\text { percentage on } \\
\text { the territory, \% }\end{array}$ & $\begin{array}{c}\text { Intensity of } \\
\text { waterlogging, \% }\end{array}$ & $\begin{array}{c}\text { Length, } \\
\text { km }\end{array}$ & $\begin{array}{c}\text { Water } \\
\text { discharges, } \\
\mathbf{m}^{\mathbf{3}} / \mathbf{s}\end{array}$ \\
\hline 1 & Neva & 281000 & 0 & 0 & 74 & 2500.0 \\
2 & Volkhov & 13000 & 0 & 8.7 & 224 & 569.0 \\
3 & Svir & 9820 & 1.0 & 14.0 & 224 & 653.0 \\
4 & Syas & 7330 & 1.0 & 16.0 & 260 & 65.0 \\
5 & Burnaya* & 7130 & 10.0 & 3.6 & 156 & 642.0 \\
6 & Vuoksa & 7130 & 10.0 & 3.6 & 156 & 642.0 \\
7 & Pasha & 6650 & 1.0 & 18.0 & 242 & 78.0 \\
8 & Oyat & 5220 & 3.0 & 11.0 & 266 & 59.0 \\
9 & Yanis & 3900 & 14.0 & 5.0 & 126 & 41.7 \\
10 & Olonka & 2620 & 3.0 & 10.0 & 87 & 35.0 \\
11 & Tulema & 1720 & 5.0 & 16.0 & 55 & 21.8 \\
12 & Tohma & 1602 & 6.0 & 9.6 & 74 & 9.2 \\
13 & Kokkalan & 1370 & 14.0 & 4.0 & 60 & 10.7 \\
14 & Vidlitsa & 1320 & 9.0 & 9.0 & 67 & 18.5 \\
15 & Uksun & 1080 & 6.0 & 9.0 & 121 & 15.0 \\
16 & Tuloksa & 900 & 0 & 11.0 & 77 & 8.6 \\
17 & Lava & 529 & 3.3 & 0 & 31 & 4.2 \\
18 & Morje & 478 & 0 & 0 & 43 & 4.0 \\
19 & Avloga & 385 & 2.0 & 0 & 54 & 1.0 \\
20 & Nasiya & 332 & 0.8 & 0 & 42 & 2.1 \\
\hline
\end{tabular}

* - data for a single river-lake system Vuoksa.

The following parameters of catchment basins of Lake Ladoga major tributaries were used: river length $(\mathrm{L}, \mathrm{km})$, areas of wetlands $\left(\mathrm{Sh}_{\mathrm{wet}}, \%\right)$, lake percentage on the territory of the catchment basin $\left(\mathrm{Sh}_{\text {lakes }}, \%\right)$, catchment area $\left(\mathrm{S}_{\mathrm{cat}}, \mathrm{km}^{2}\right)$, river flow rate $\left(\mathrm{W}_{\mathrm{fl}}, \mathrm{m}^{3} / \mathrm{s}\right)($ Table 1$)$. 
Zooplankton samples were collected from the shore at open areas lacking macrophytes by pouring $100 \mathrm{~L}$ of water through the Apstein cone-shaped net (mesh size is $75 \mu \mathrm{m}$ ) and fixed in $40 \%$ formalin (diluted to $4.0 \%$ ). Species composition and qualitative development patterns of rotifers of the tributaries zooplankton were assessed after processing the sediment samples. The material was processed according to the routine protocols described by Abakumov (1992). Biomass of the organisms (raw formalin weight) was calculated using the formulas for the dependence between body length and weight of planktonic crustaceans (Ruttner-Kolisko, 1977; Balushkina and Vinberg, 1979). Species composition was determined with the help of identification manuals (Rylov, 1963; Kutikova, 1970; Alekseev and Tsalolikhin (eds.), 2010).

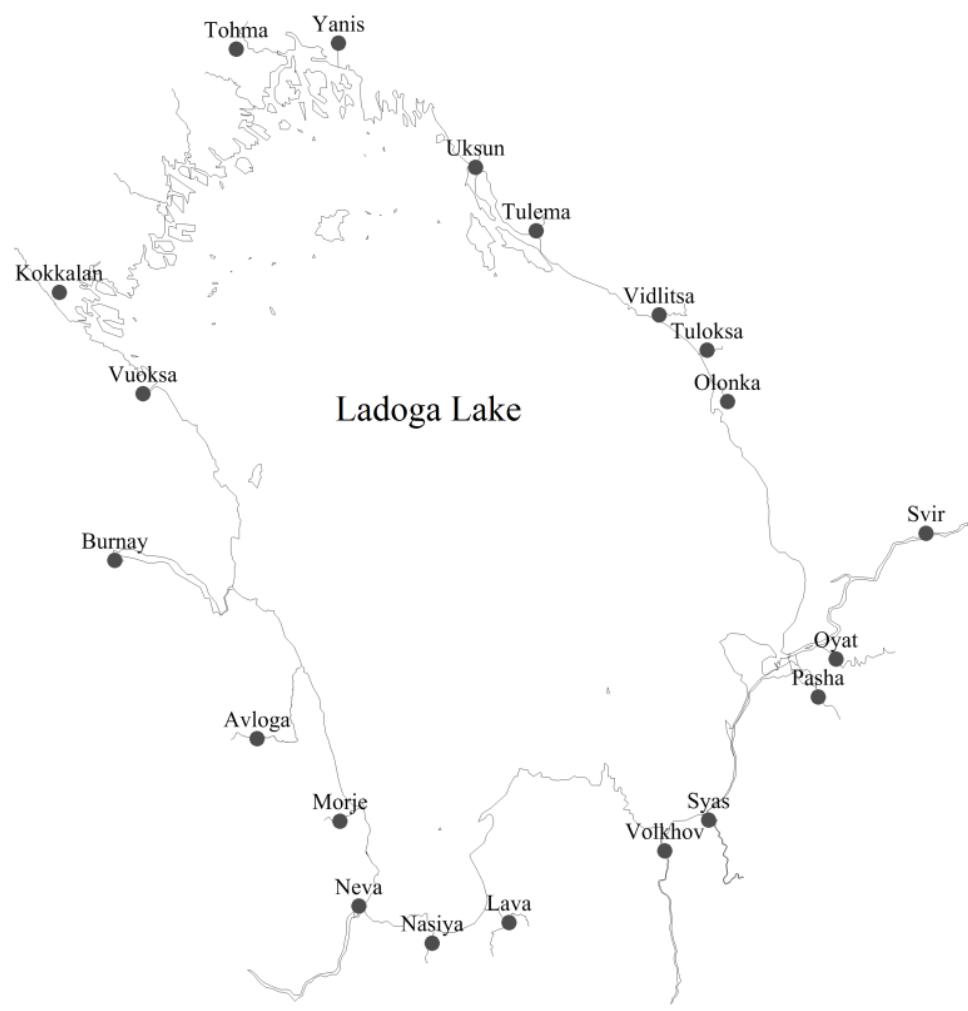

Figure 1. Scheme of sampling stations on the tributaries of Lake Ladoga and Neva River

The following parameters were used to characterize the zooplankton community: number of species $(\mathrm{n})$, abundance $\left(\mathrm{N}\right.$, ind. $\left./ \mathrm{m}^{3}\right)$, biomass $\left(\mathrm{B}, \mathrm{mg} / \mathrm{m}^{3}\right)$, the Shannon diversity index (Shannon, 1948) estimated for both abundance $\left(\mathrm{H}_{\mathrm{N}}\right.$, bit/ind.) and biomass $\left(\mathrm{B}_{\mathrm{N}}, \mathrm{bit} / \mathrm{mg}\right)$. To separate groups of rivers, similar in zooplankton, the numbers of individual species of Copepoda, Cladocera, and Rotifera, and members of Copepoda, Cladocera, and Rotifera groups that have not been identified to species (Copepodits of Calanoida, Copepodits of Cyclopoida, Nauplii of Calanoida, Nauplii of Cyclopoida, Cyclopoida spp.) (86 variables in total), as well as total numbers of Copepoda, Cladocera, and Rotifera were used.

Statistical analysis of the variables was performed for each time period. Cluster analysis, correlation analysis and regression analysis (stepwise multiple regression) included in Statistica 6.0 software package (StatSoft Inc.) were used to reveal 
interrelationships between the studied parameters. The authors used the modification of cluster analysis, where the variables correlation measure was Euclidean distance or Pearson correlation coefficient; individual rivers were included into clusters according to the complete linkage method or Ward method (Pesenko, 1982).

\section{Results}

\section{Chemical composition}

Chemical composition of water in tributaries of Lake Ladoga is typical for the area under study, its common features result from similar climate conditions, and the differences are caused by peculiarities of geomorphologic characteristics, the composition of the rocks (Appendix A).

The waters of tributaries of Lake Ladoga fall into the hydrocarbonate class of calcium group. Calcium ions prevail in the cationic composition of water of all rivers 1.6 to $52.63 \mu \mathrm{g} / \mathrm{L}$, the content of magnesium ions varies from 0.7 to $16.2 \mu \mathrm{g} / \mathrm{L}$, the content of sodium and potassium ions - from 0.08 to $19.95 \mu \mathrm{g} / \mathrm{L}$. The content of sulphates varies from $1.82 \mathrm{mg} / \mathrm{L}$ (the Uksun River) to $17.00 \mathrm{mg} / \mathrm{L}$ (the Kokkolan River), the content of chlorides - from $1.03 \mathrm{mg} / \mathrm{L}$ (the Uksun River) to $19.14 \mathrm{mg} / \mathrm{L}$ (the Volkhov River), the content of carbonates - from $0.73 \mathrm{mg} / \mathrm{L}$ (the Uksun River) to $185.93 \mathrm{mg} / \mathrm{L}$ (the Lava River). During the period of studies, the water temperature was above $3.5^{\circ} \mathrm{C}$ and below $22.5^{\circ} \mathrm{C}$.

\section{Community composition and quantitative patterns of zooplankton development}

In the investigated rivers, a total of 137 zooplankton taxa ranking below genus were identified in the lower course of the Lake Ladoga tributaries and the Neva River head. Rotifera group accounted for 56 species and subspecies (40.9\%), Cladocera - 57 (41.6\%), Copepoda - 24 (17.5\%), including 6 members of Calanoida (4.4\%), 18 Cyclopoida (13.1\%). The greatest number of species was found in large rivers: the Vuoksa (57), the Burnaya (51), the Volkhov (49), the Svir (45), the Neva (45), the lowest number - in the Kokkolan River (26) (Appendix B).

Species composition considerably varied between different rivers. A. harpae, B. (E.) coregoni, $C$. sphaericus were the only crustaceans found in all rivers. Almost every tributary was inhabited by following zooplankters: A. priodonta (except for the Naziya River), E. lyra (except for the Pasha River), B. (B.) longirostris (except for the Vidlitsa River), M. leuckarti (except for the Tokhma River and the Vidlitsa River). Such members of lower crustaceans as B. (E.) coregoni (frequency of occurrence, $\mathrm{F}=11.5 \%)$, C. sphaericus $(\mathrm{F}=11.5 \%)$, B. (B.) longirostris $(\mathrm{F}=9.6 \%)$, A. harpae $(\mathrm{F}=9.3 \%)$, P. pediculus $(\mathrm{F}=9.3 \%)$, D. cristata Sars $(\mathrm{F}=7.6 \%)$, and such rotifers as Synchaeta spp. $(\mathrm{F}=12.4 \%)$, A. priodonta $(\mathrm{F}=10.4 \%), C$. unicornis $(\mathrm{F}=7.6 \%), K$. longispina $(\mathrm{F}=7.1 \%)$, Bdelloida spp. $(\mathrm{F}=5.4 \%)$, B. hudsoni $(\mathrm{F}=4.3 \%)$, E. incisa $(\mathrm{F}=3.8 \%)$, K. quadrata $(\mathrm{F}=3.2 \%)$, A. herricki $(\mathrm{F}=2.7 \%)$ were the most abundant in the zooplankton samples.

As a rule, several species simultaneously prevailed in the rivers. Among Cladocera B. (E.) coregoni was dominant more often than any other zooplankters (Table 3). The members of the lake complex - A. priodonta, K. longispina, C. unicornis, D. (D.) cristata, E. gracilis, T. oithonoides, as well as the crustaceans of the littoral macrophyte complex - A. harpae, A. quadrangularis, $C$. sphaericus prevailed in most tributaries. 
Plankton community was formed by 53 cosmopolitan species (43.8\%), 32 holarctic species $(25.4 \%), 31$ palaearctic species $(25.6 \%), 5$ boreal species $(4.1 \%)$.

The highest numbers of zooplankton within the Lake Ladoga tributaries were observed in the Avloga River in May 2011 (9580 ind. $/ \mathrm{m}^{3}$ ), in the Tuloksa River and the Burnaya River in June 2014 (9190 ind. $/ \mathrm{m}^{3}$ each). The highest levels of biomass development were observed in the zooplankton communities of the Vuoksa River in May $2015\left(266.2 \mathrm{mg} / \mathrm{m}^{3}\right)$, in the Tuloksa River in June $2014\left(256.5 \mathrm{mg} / \mathrm{m}^{3}\right)$. The lowest levels of population and biomass (30 ind. $/ \mathrm{m}^{3}$ and $0.17 \mathrm{mg} / \mathrm{m}^{3}$ respectively) were observed in small rivers (the Tokhma River, the Uksun River). The mean levels of population in the tributaries during the study period of 2011-2014 varied from high $2870 \pm 670$ ind. $/ \mathrm{m}^{3}$ in the Vuoksa River - to low $-210 \pm 50$ ind.$/ \mathrm{m}^{3}$ in the Lava River, the levels of biomass - from $191.77 \pm 125.22 \mathrm{mg} / \mathrm{m}^{3}$ in the Vuoksa River to $1.84 \pm 0.55$ $\mathrm{mg} / \mathrm{m}^{3}$ in the Kokkolan River (Table 2).

Table 2. Mean abundance $\left(N_{\text {tot }}\right.$, ind $\left./ \mathrm{m}^{3}\right)$; biomass $\left(B_{t o t}, \mathrm{mg} / \mathrm{m}^{3}\right)$ and the values of the Shannon index, calculated on the number $\left(H_{N}\right.$, bit/ind.) and biomass $\left(H_{B}\right.$, bit/mg $)$ of zooplankton species in the tributaries of Lake Ladoga and the Neva river in 2011-2014.

\begin{tabular}{|c|c|c|c|c|c|}
\hline № & River & $\mathbf{N}_{\text {tot }}$, ind $/ \mathrm{m}^{3}$ & $B_{\text {tot }}, \mathrm{mg} / \mathrm{m}^{3}$ & $\mathrm{H}_{\mathrm{N}}$, bit/ind. & $\mathbf{H}_{\mathrm{B}}$, bit $/ \mathrm{mg}$ \\
\hline \multirow{2}{*}{1} & \multirow{2}{*}{ Neva } & $6910 \pm 3320$ & $\underline{123.87 \pm 53.97}$ & $2.24 \pm 0.10$ & $\underline{1.88 \pm 0.14}$ \\
\hline & & 1.44 & 1.31 & 0.13 & 0.22 \\
\hline \multirow{2}{*}{2} & \multirow{2}{*}{ Volkhov } & $\underline{410 \pm 130}$ & $\underline{18.19 \pm 8.28}$ & $\underline{1.84 \pm 0.16}$ & $\underline{1.52 \pm 0.18}$ \\
\hline & & 0.91 & 1.37 & 0.25 & 0.37 \\
\hline \multirow{2}{*}{3} & \multirow{2}{*}{ Svir } & $\underline{1810 \pm 880}$ & $\underline{46.72 \pm 22.11}$ & $\underline{1.84 \pm 0.25}$ & $\underline{1.63 \pm 0.20}$ \\
\hline & & 1.45 & 1.420 & 0.415 & 0.36 \\
\hline \multirow{2}{*}{4} & \multirow{2}{*}{ Syas } & $\underline{700 \pm 230}$ & $\underline{25.82 \pm 20.23}$ & $\underline{1.66 \pm 0.17}$ & $\underline{1.48 \pm 0.17}$ \\
\hline & & 0.97 & 2.35 & 0.31 & 0.34 \\
\hline \multirow{2}{*}{5} & \multirow{2}{*}{ Burnaya } & $\underline{2680 \pm 1000}$ & $\underline{62.58 \pm 27.93}$ & $\underline{2.30 \pm 0.16}$ & $\underline{2.17 \pm 0.13}$ \\
\hline & & 1.12 & 1.34 & 0.21 & 0.18 \\
\hline \multirow{2}{*}{6} & \multirow{2}{*}{ Vuoksa } & $\underline{2870 \pm 670}$ & $\underline{191.77 \pm 125.22}$ & $\underline{2.40 \pm 0.15}$ & $\underline{2.14 \pm 0.16}$ \\
\hline & & 0.70 & 1.96 & 0.19 & 0.22 \\
\hline \multirow{2}{*}{7} & \multirow{2}{*}{ Pasha } & $\underline{420 \pm 110}$ & $\underline{13.11 \pm 10.12}$ & $1.63 \pm 0.27$ & $\underline{1.47 \pm 0.23}$ \\
\hline & & 0.76 & 2.32 & 0.49 & 0.48 \\
\hline \multirow{2}{*}{8} & \multirow{2}{*}{ Oyat } & $\underline{660 \pm 180}$ & $9.17 \pm 2.99$ & $1.80 \pm 0.20$ & $\underline{1.65 \pm 0.16}$ \\
\hline & & 0.81 & 0.98 & 0.33 & 0.29 \\
\hline \multirow{2}{*}{9} & \multirow{2}{*}{ Yanis } & $\underline{410 \pm 80}$ & $\underline{8.38 \pm 2.34}$ & $\underline{1.88 \pm 0.27}$ & $\underline{1.63 \pm 0.28}$ \\
\hline & & 0.61 & 0.84 & 0.44 & 0.51 \\
\hline \multirow{2}{*}{10} & \multirow{2}{*}{ Olonka } & $\underline{1070 \pm 410}$ & $\underline{17.46 \pm 4.67}$ & $2.06 \pm 0.14$ & $\underline{1.88 \pm 0.14}$ \\
\hline & & 1.17 & 0.80 & 0.20 & 0.22 \\
\hline \multirow{2}{*}{11} & \multirow{2}{*}{ Tulema } & $\underline{860 \pm 460}$ & $9.95 \pm 4.27$ & $1.89 \pm 0.21$ & $\underline{1.48 \pm 0.19}$ \\
\hline & & 1.60 & 1.29 & 0.33 & 0.38 \\
\hline \multirow{2}{*}{12} & \multirow{2}{*}{ Tohma } & $\underline{290 \pm 90}$ & $\underline{5.28 \pm 1.68}$ & $\underline{1.67 \pm 0.25}$ & $\underline{1.32 \pm 0.20}$ \\
\hline & & 0.90 & 0.96 & 0.45 & 0.46 \\
\hline
\end{tabular}




\begin{tabular}{|c|c|c|c|c|c|}
\hline № & River & $\mathrm{N}_{\text {tot }}$, ind $/ \mathrm{m}^{3}$ & $\mathbf{B}_{\text {tot }}, \mathrm{mg} / \mathrm{m}^{3}$ & $\mathbf{H}_{\mathrm{N}}$, bit/ind. & $\mathrm{H}_{\mathrm{B}}$, bit $/ \mathrm{mg}$ \\
\hline \multirow{2}{*}{13} & \multirow{2}{*}{ Kokkalan } & $\underline{180 \pm 40}$ & $\underline{1.84 \pm 0.55}$ & $\underline{1.54 \pm 0.15}$ & $1.34 \pm 0.21$ \\
\hline & & 0.66 & 0.90 & 0.29 & 0.48 \\
\hline \multirow{2}{*}{14} & \multirow{2}{*}{ Vidlitsa } & $\underline{270 \pm 80}$ & $\underline{4.48 \pm 1.83}$ & $\underline{1.45 \pm 0.17}$ & $\underline{1.10 \pm 0.15}$ \\
\hline & & 0.87 & 1.23 & 0.36 & 0.40 \\
\hline \multirow{2}{*}{15} & \multirow{2}{*}{ Uksun } & $\underline{540 \pm 290}$ & $\underline{7.17 \pm 3.43}$ & $\underline{1.89 \pm 0.21}$ & $\underline{1.42 \pm 0.28}$ \\
\hline & & 1.61 & 1.43 & 0.34 & 0.58 \\
\hline \multirow{2}{*}{16} & \multirow{2}{*}{ Tuloksa } & $\underline{1990 \pm 1210}$ & $\underline{68.97 \pm 35.77}$ & $1.67 \pm 0.20$ & $\underline{1.41 \pm 0.22}$ \\
\hline & & 1.72 & 1.56 & 0.36 & 0.46 \\
\hline \multirow{2}{*}{17} & \multirow{2}{*}{ Lava } & $\underline{210 \pm 50}$ & $\underline{3.47 \pm 1.87}$ & $\underline{1.86 \pm 0.12}$ & $\underline{1.58 \pm 0.24}$ \\
\hline & & 0.65 & 1.42 & 0.17 & 0.40 \\
\hline \multirow{2}{*}{18} & \multirow{2}{*}{ Morje } & $\underline{500 \pm 150}$ & $\underline{7.52 \pm 2.23}$ & $\underline{1.94 \pm 0.15}$ & $\underline{1.75 \pm 0.19}$ \\
\hline & & 0.87 & 0.89 & 0.23 & 0.33 \\
\hline \multirow{2}{*}{19} & \multirow{2}{*}{ Avloga } & $\underline{1450 \pm 1030}$ & $\underline{8.08 \pm 3.54}$ & $\underline{1.52 \pm 0.18}$ & $\underline{1.25 \pm 0.13}$ \\
\hline & & 2.13 & 1.31 & 0.35 & 0.30 \\
\hline \multirow{2}{*}{20} & \multirow{2}{*}{ Nasiya } & $\underline{350 \pm 100}$ & $\underline{5.99 \pm 2.07}$ & $\underline{1.74 \pm 0.15}$ & $\underline{1.48 \pm 0.16}$ \\
\hline & & 0.89 & 1.04 & 0.26 & 0.32 \\
\hline
\end{tabular}

Note: above the line - the arithmetic mean \pm standard error of the mean, below the line - the coefficient of variation of the characteristics.

The highest numbers of population and biomass at the station of the Neva River head were observed in August 2011 (29360 ind. $/ \mathrm{m}^{3}$ and $468.3 \mathrm{mg} / \mathrm{m}^{3}$ respectively), whereas the lowest ones - in May 2015 (480 ind.$/ \mathrm{m}^{3}$ and $4.65 \mathrm{mg} / \mathrm{m}^{3}$ respectively). Mean value of zooplankton abundance was $6910 \pm 3320$ ind. $/ \mathrm{m}^{3}$, mean biomass $-123.87 \pm 53.97$ $\mathrm{mg} / \mathrm{m}^{3}$ (Table 2).

The values of the Shannon index for zooplankton abundance $\left(\mathrm{H}_{\mathrm{N}}\right)$ varied from 0.29 bit/ind. (the Pasha River) to 3.07 bit/ind. (the Vuoksa River) and from $0.18 \mathrm{bit} / \mathrm{mg}$ (the Yanis River) to $2.89 \mathrm{bit} / \mathrm{mg}$ (the Vuoksa River) for zooplankton biomass $\left(\mathrm{B}_{\mathrm{N}}\right)$.

Mean values of Rotifera abundance were higher than those of the crustaceans in the Tuloksa and the Morje rivers, mean biomass - in the Burnaya, the Tuloksa, the Morje, the Kokkolan rivers. The Copepoda crustaceans prevailed in both number and biomass in the zooplankton communities of the Neva head and the Volkhov mouth. Mean values of number and biomass of Cladocera were higher than total values of other zooplankton groups in the rest of the rivers (Figs. 2, 3).

\section{Statistical analysis}

Cluster analysis of the variables was performed for 9 time periods: May, August, and October 2011, July and October 2012, June and September 2013, May and July 2014.

When clustering rivers according to the species composition and species abundance, no similar clusters could be formed both in different seasons of the same year and in different years (Figs. 4-7). 
Ntot, ind $/ \mathrm{m}^{3}$

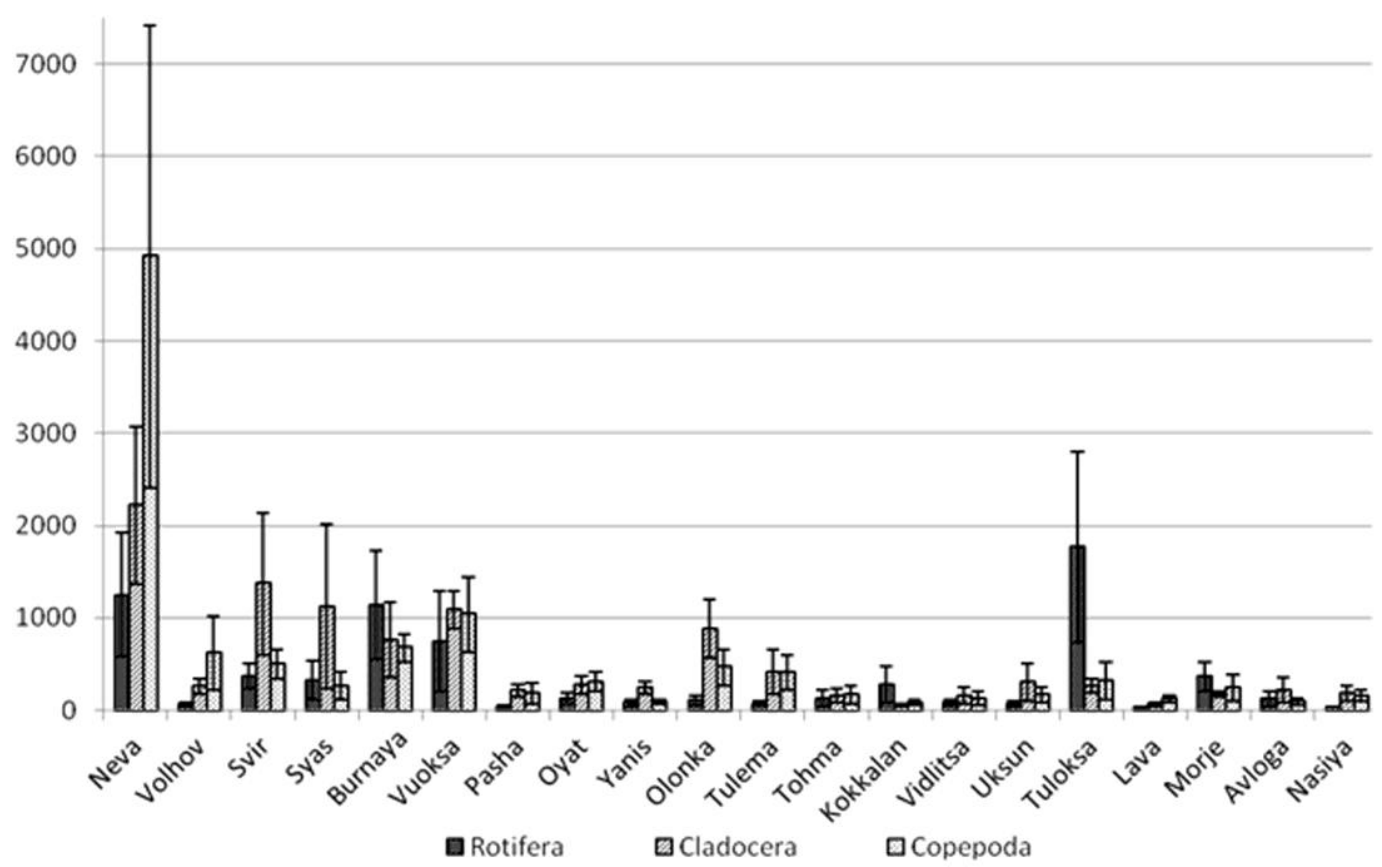

Figure 2. The average values of the number of major zooplankton groups in 2011-2014

Btot, $\mathrm{mg} / \mathrm{m}^{3}$

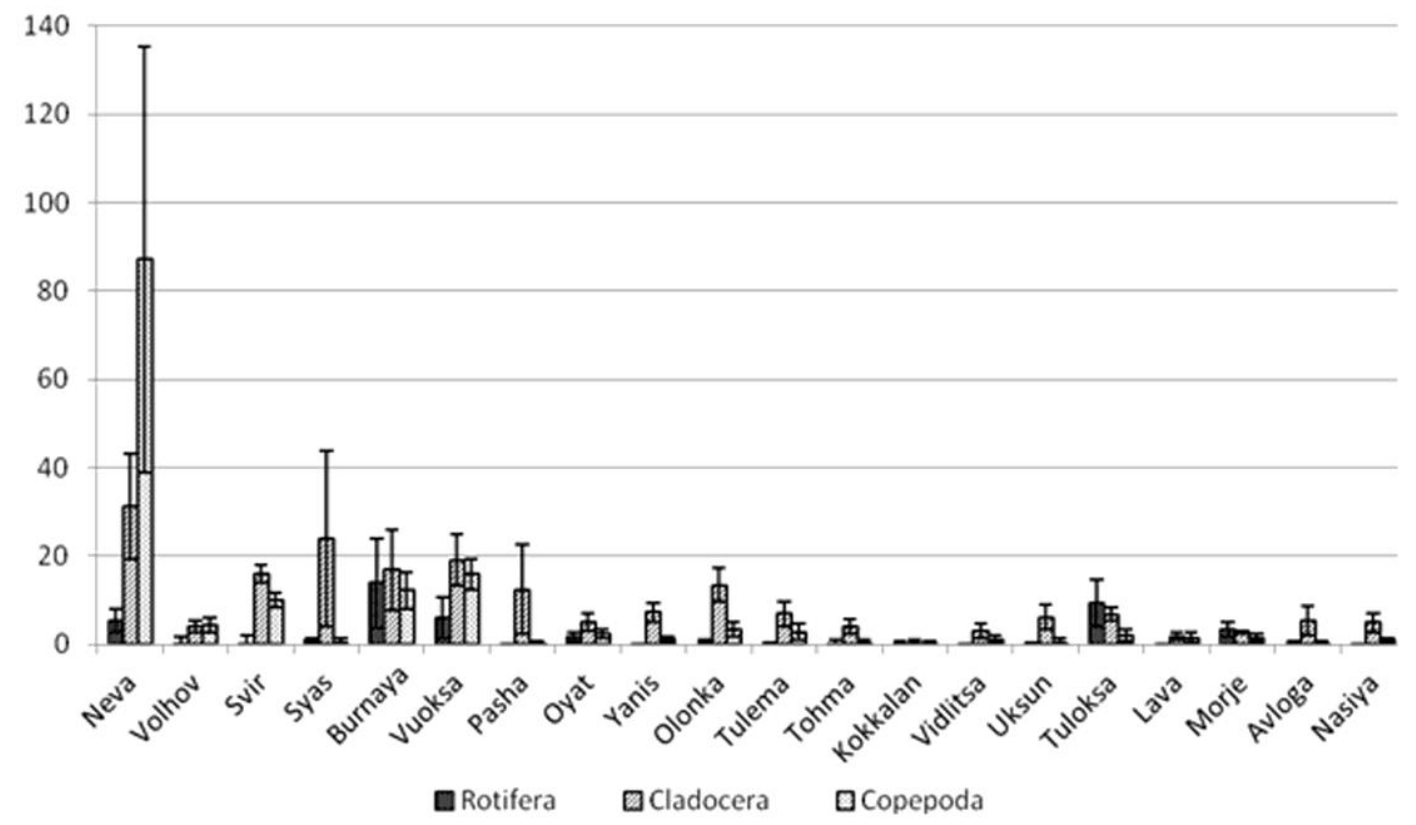

Figure 3. The average values of the biomass of major zooplankton groups in 2011-2014 

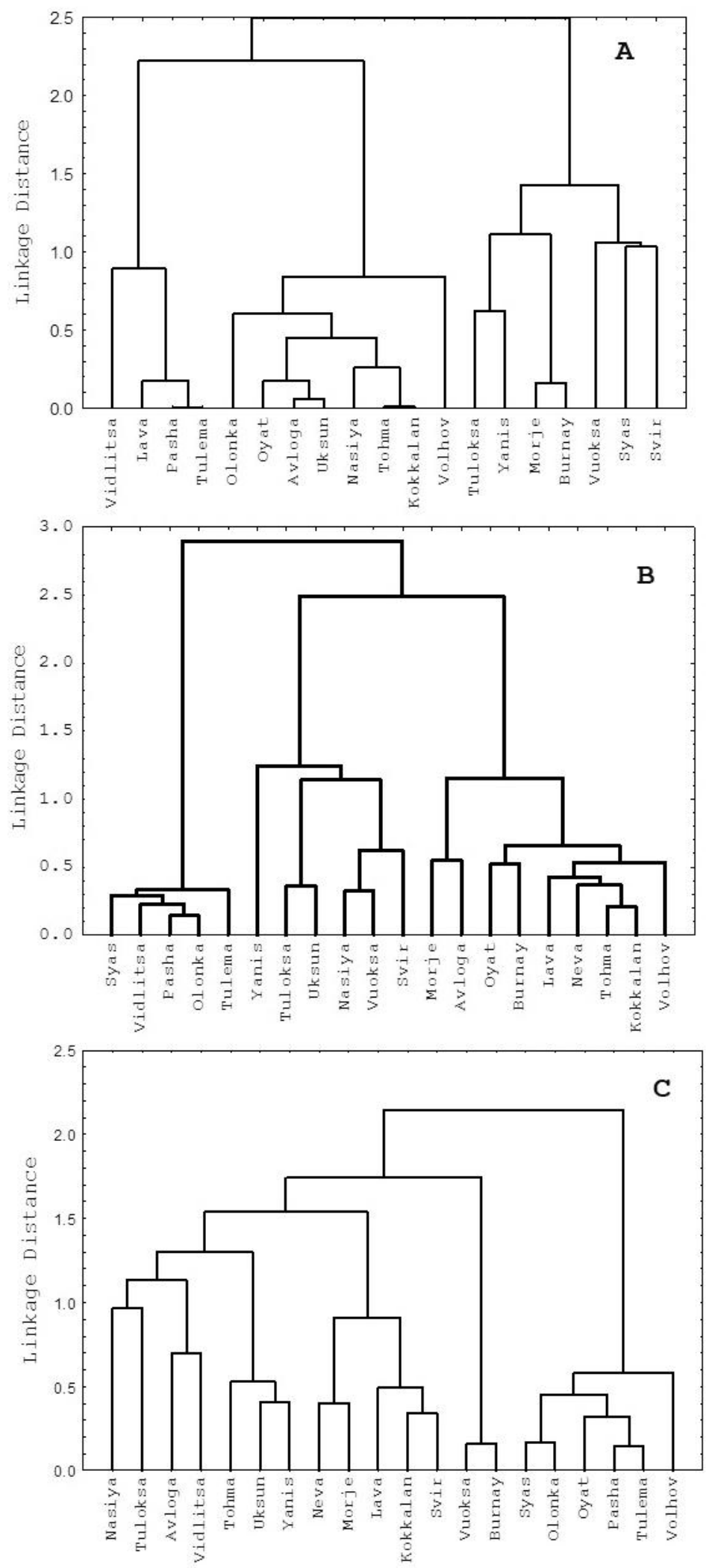

Figure 4. Diagram of similarities of tributaries of Lake Ladoga in 2011, based on the analysis of the composition and abundance of zooplankton species (joining by the Ward's method, distance measure - Pearson correlation coefficient). A-May, B-August, C-October. 
River groups of the Vidlitsa-Pasha-Tulema and the Tokhma-Kokkolan-Volkhov showed similar trends of clustering in spring and summer 2011; the Lava-Kokkolan and the Syas-Olonka - in summer and autumn; the Pasha-Tulema - in spring and autumn (Fig. 4).

In 2012, the rivers did not form similar clusters for different time periods, when the analysis was based on the numbers of individual zooplankton species (Fig. 5).

In 2013, similar trends of clustering were observed in case of the Kokkolan-Volkhov rivers in summer and autumn (Fig. 6).
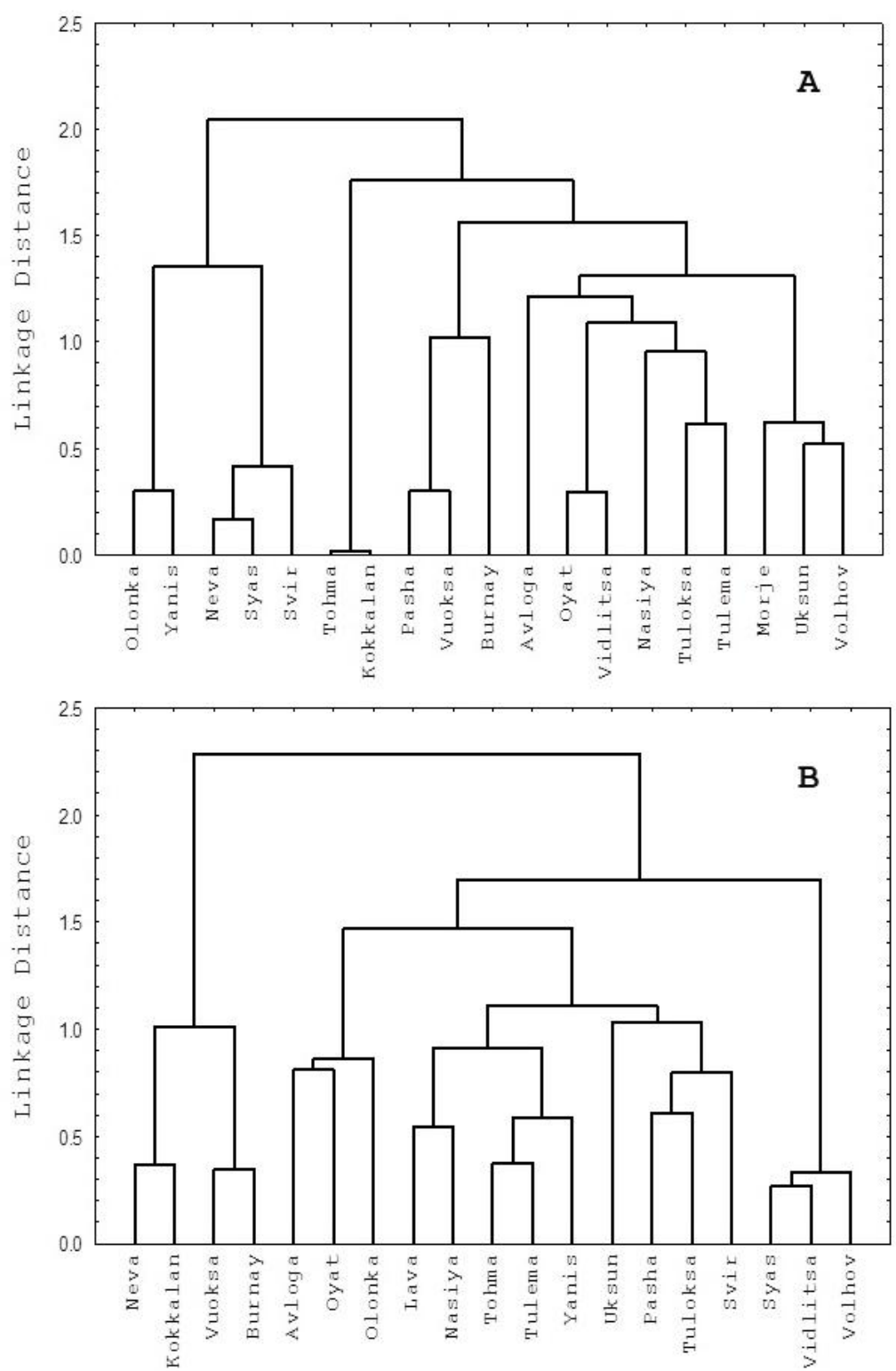

Figure 5. Diagram of similarities of tributaries of Lake Ladoga in 2012, based on the analysis of the composition and abundance of zooplankton species (joining by the Ward's method, distance measure - Pearson correlation coefficient). A-July, B-October. 

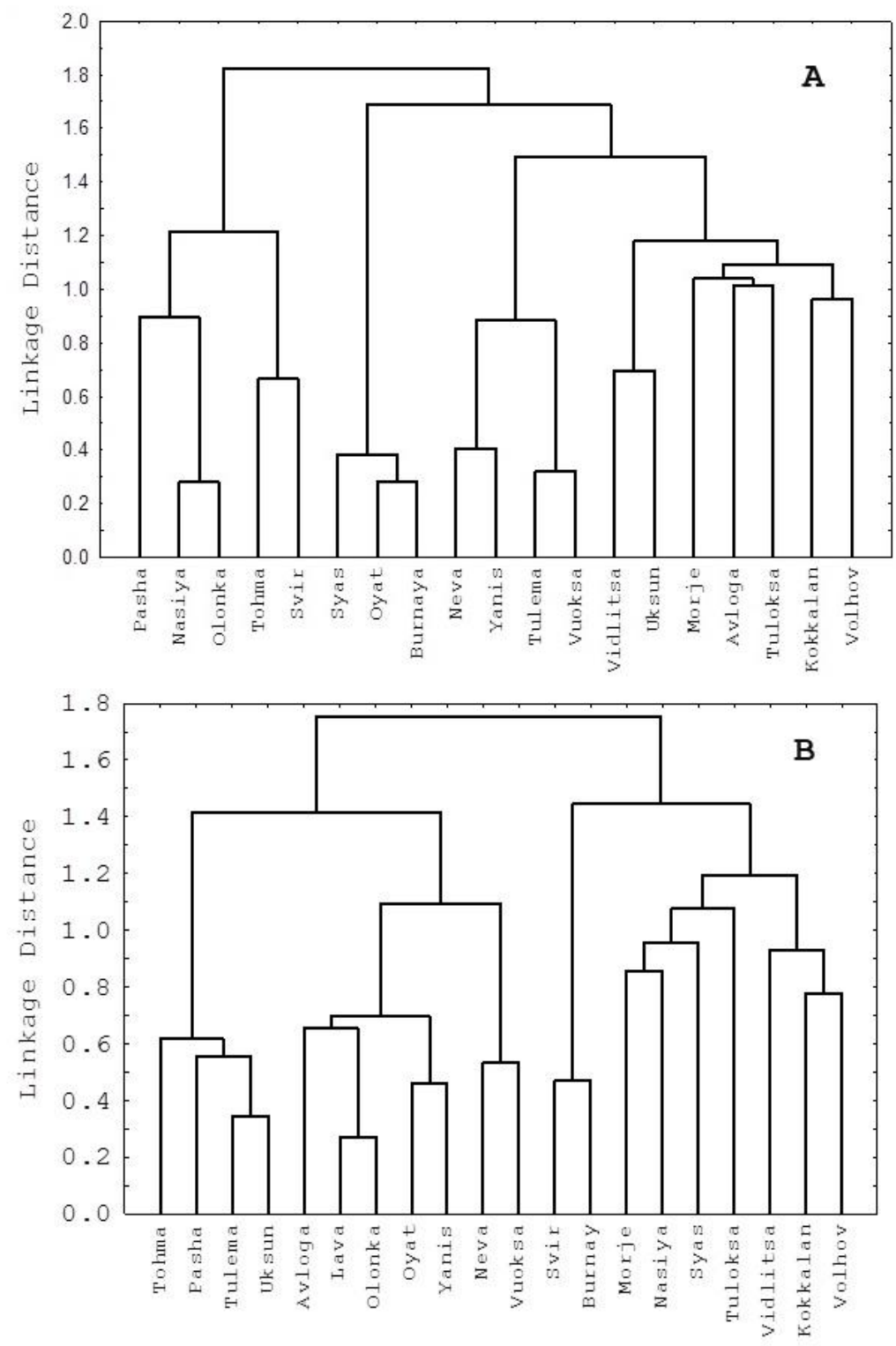

Figure 6. Diagram of similarities of tributaries of Lake Ladoga in 2013, based on the analysis of the composition and abundance of zooplankton species (joining by the Ward's method, distance measure - Pearson correlation coefficient). A-June, B-September.

In 2014, similar trends of clustering were only observed in case of the Lava-Pasha rivers and the Oyat-Naziya-Volkhov rivers in spring and summer (Fig. 7).

The examples of river clustering based on the hydrochemical, hydrological parameters and the catchment basin features (4 periods of 9) are shown in Fig. 8.

In general, the clusters of rivers similar in zooplankton communities did not coincide with the clusters of rivers that considered all the hydrochemical, hydrological parameters and the catchment basin features, in any year of studies (Fig. 8).

Generally, the clustering based on the hydrochemical, hydrological parameters and the catchment basin features was consistent in different years and seasons. Similar rivers were grouped according to their physiographic position (Fig. 8). 

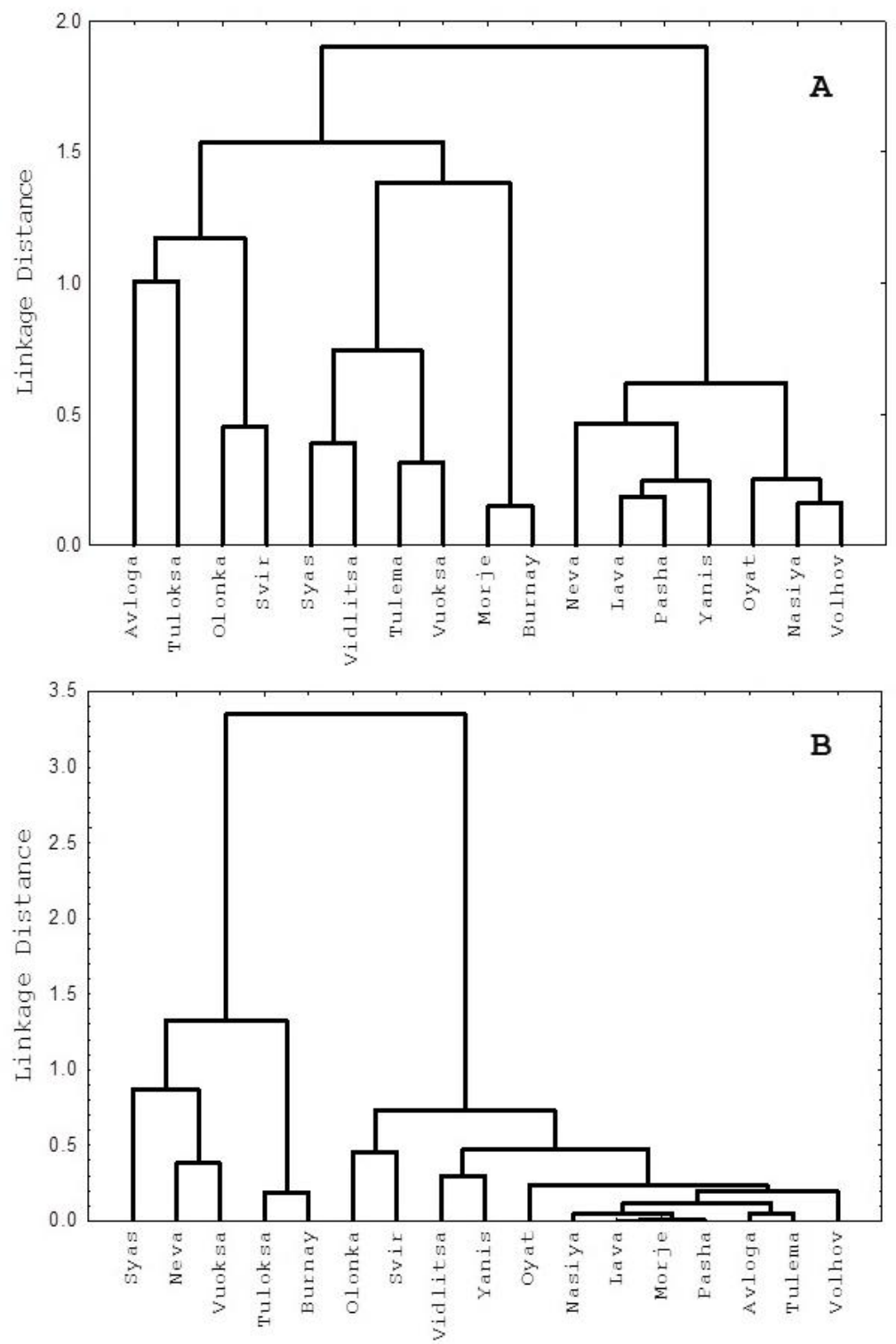

Figure 7. Diagram of similarities of tributaries of Lake Ladoga in 2014, based on the analysis of the composition and abundance of zooplankton species (joining by the Ward's method, distance measure - Pearson correlation coefficient). A-May, B-July.

The results of regression and correlation analysis did not show significant $(\mathrm{p}<0.05)$ relationship between the parameters of the development of individual zooplankton species and the assessed parameters of water of the Lake Ladoga tributaries.

Unlike the regression analysis that failed to show connection between the development of zooplankton species and the environmental factors, and to provide significant $(\mathrm{p}<0.05)$ equations of regression, the analysis of total numbers of Copepoda, Cladocera, and Rotifera resulted in highly significant correlations. 8 of 9 possible significant regression equations describing the group size as a function of a certain set of variables were obtained for Copepoda, 7 - for Rotifera, 6 - for Cladocera (Table 3). 

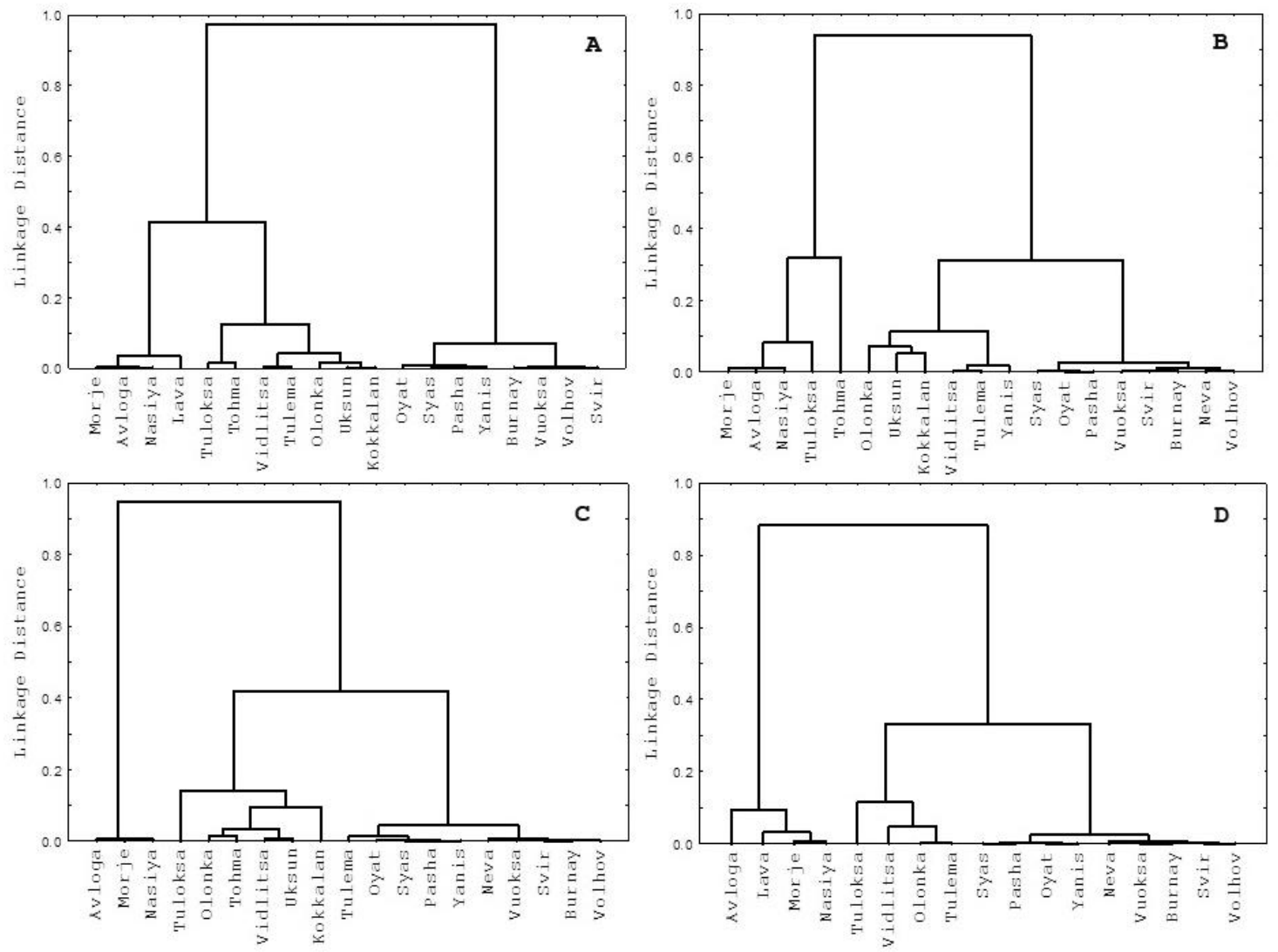

Figure 8. Diagrams of similarities of tributaries of Lake Ladoga in different years, based on the analysis of the hydrochemical, hydrological parameters and characteristics of the catchment. (A: May 2011; B: July 2012; C: June 2013; D: May 2014) (joining by the Complete Linkage, distance measure - Pearson coefficient).

The coefficient of determination (adjusted $\mathrm{R}^{2}$ ) for the resulting equations varied from 0.4975 to 1.000 (Table 3). The range of the regression significance ( $\mathrm{p}$ ) was 0.00950.0000 . The examples of the obtained regressions for each year and group are shown in Figs. 9-12.

Table 3. The number of significant regressions $(p<0.05)(\max =9)$, the range of adjusted $R^{2}$ and the range of significance of obtained regression ( $p$ ) for Copepoda, Cladocera and Rotifera in the tributaries of Lake Ladoga.

\begin{tabular}{c|c|c|c}
\hline Group & $\begin{array}{c}\text { The number } \\
\text { of significant } \\
\text { regressions } \\
(\mathbf{p}<\mathbf{0 . 0 5})\end{array}$ & $\begin{array}{c}\text { The range of } \\
\text { adjusted } \mathbf{R}^{\mathbf{2}}\end{array}$ & $\begin{array}{c}\text { The range of } \\
\text { significance of } \\
\text { regressions }(\mathbf{p})\end{array}$ \\
\hline Copepoda & 8 & $0.5570-1.0000$ & $0.0032-0.0000$ \\
Rotifera & 7 & $0.6322-1.0000$ & $0.0095-0.0000$ \\
Cladocera & 6 & $0.4975-0.9999$ & $0.0095-0.0000$ \\
\hline
\end{tabular}



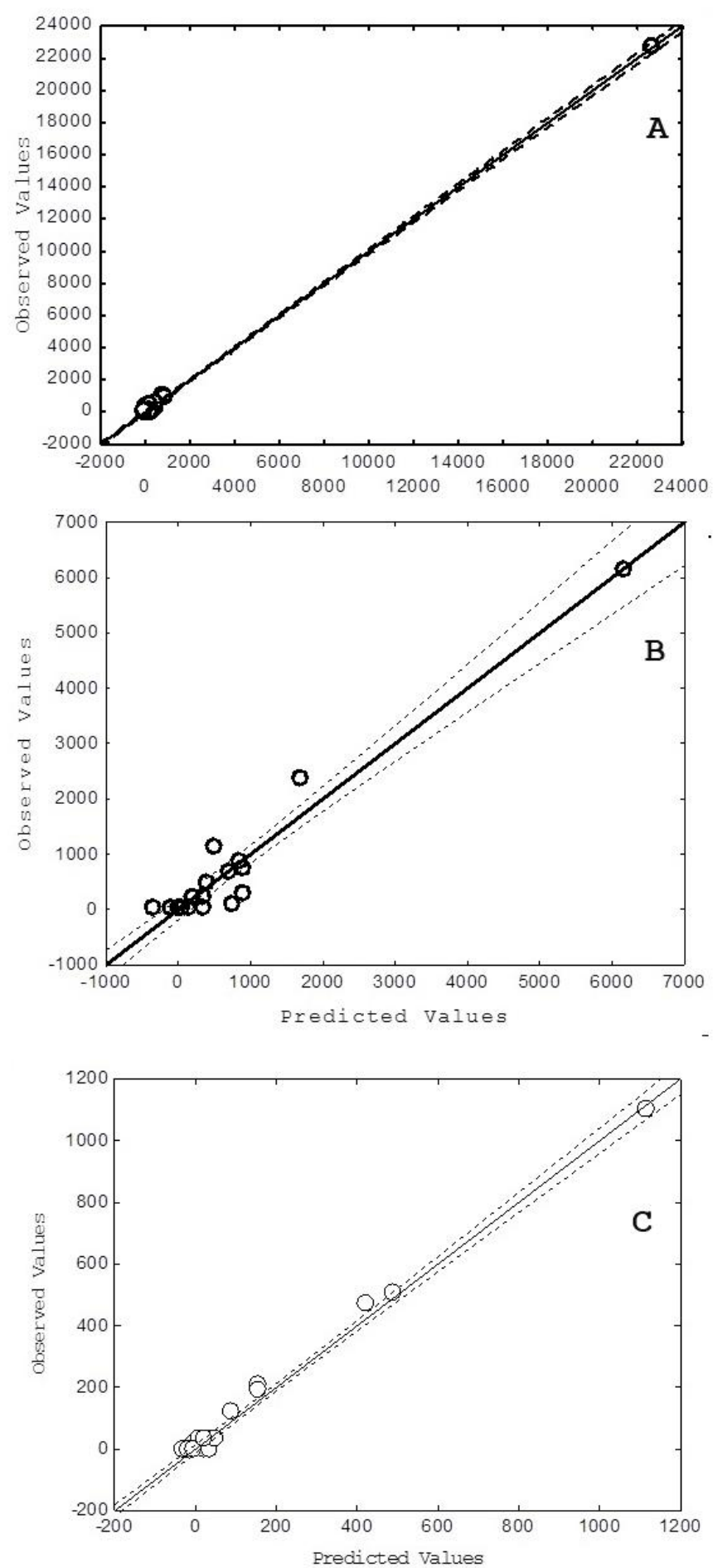

Figure 9. Regression models relating the number of the groups of zooplankton with environmental factors for 2011 :

A: Copepoda $=0.08 S_{\text {cat }}-2761 \mathrm{Mg}+1132 \mathrm{pH}+0.19 \mathrm{Fe}+26.07 \mathrm{Wet}+982 \mathrm{SO}_{4}-7940\left(\right.$ August. $\left.R^{2}=0.9984\right) ; \mathrm{B}:$

Cladocera $=0.02$ Scat $-3877 \mathrm{Mg}+2580(\mathrm{Na}+\mathrm{K})-0.76 \mathrm{Al}-$

$164 \mathrm{Cu}+5512 \mathrm{Cl}+916 \mathrm{SO}_{4}+80.27 \mathrm{Sh}_{\text {wetl }}+3.78 \mathrm{Wcol}+110$ (August. $\left.R^{2}=0.8909\right) ; \mathrm{C}:$ Rotifera $=5186 \mathrm{SO}_{4}$ $1.353 W_{f l}+2424 \mathrm{Cl}-0.698 \mathrm{Al}+6.439 \mathrm{~L}+2.460 \mathrm{~W}_{\text {col }}+2498 \mathrm{Ca}-0.098 \mathrm{Fe}+0.013 \mathrm{~S}_{\text {cat }}+4711(\mathrm{Na}+\mathrm{K})-3.485 \mathrm{P}_{\text {tot }}-$ 38.105TDS-24.373Sh lakes $+14.15 C O D-27.602 C u-179 P b-768\left(\right.$ August. $\left.^{2}=0.9464\right)$. 

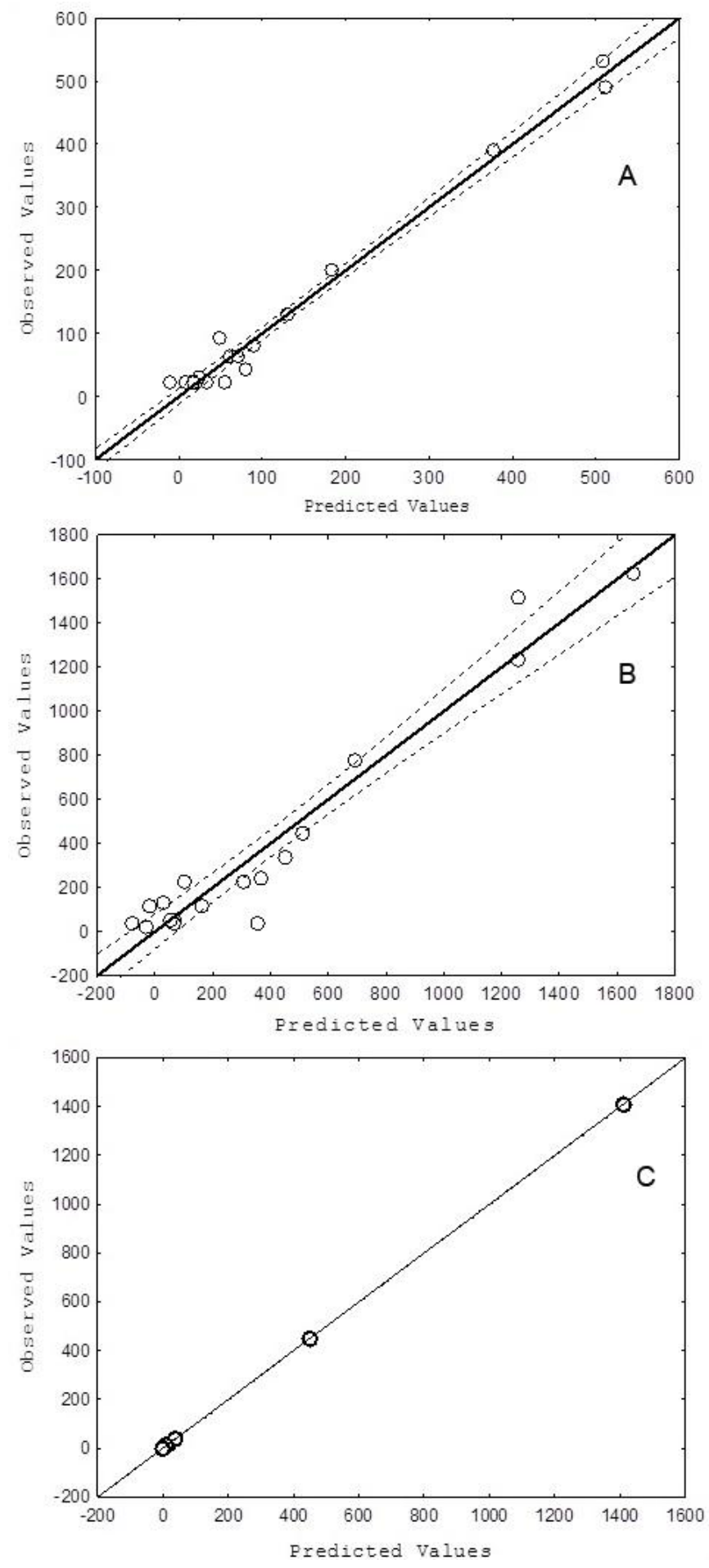

Figure 10. Regression models relating the number of the groups of zooplankton with environmental factors for 2012:

A: Copepoda $=0.442 W_{\text {col }}-56 \mathrm{Ca}-0.006 \mathrm{~S}_{\text {cat }}+0.797 \mathrm{~W}_{f l}+11.86 \mathrm{HCO}_{3}-7.95 \mathrm{Sh}_{\text {wetl }}-24.94 \mathrm{~Pb}-$

$6.290 \mathrm{Cu}+14.99 \mathrm{Sh}_{\text {lakes }}+0.06 \mathrm{Fe}-0.396 \mathrm{Mn}-18\left(\right.$ July. $\left.R^{2}=0.9614\right) ; B:$ Cladocera $=+1.084 W_{f l}$ $+1.968 P_{\text {tot }}+63.12$ Sh $_{\text {lakes }}-1.861 B G A-42.84 C u+2.126 M n+1.32 W_{\text {col }}+99.22 P b-697\left(\right.$ July. $\left.R^{2}=0.8939\right) ; C$ :

Rotifera $=159.1 \mathrm{Chl}-6.5 \mathrm{BGA}+15.9 \mathrm{ORP}-0.4 \mathrm{Fe}+2318 \mathrm{pH}-47.9 \mathrm{Sh}_{\text {wetl }}$

$21.7 \mathrm{HCO}_{3}+0.009 \mathrm{~S}_{\text {cat }}+0.4 \mathrm{~L}+113.9 \mathrm{Cu}+180.2 \mathrm{SO}_{4}-204.9 \mathrm{~Pb}+1502 \mathrm{NH}_{4}-47.8(\mathrm{Na}+\mathrm{K})-11.3 \mathrm{Sh}_{\text {lakes }}{ }^{-}$ $3758 T D S+34.7 \mathrm{Mg}-1.4 \mathrm{Cl}-18631$ (July. $\left.R^{2}=1.000\right)$. 

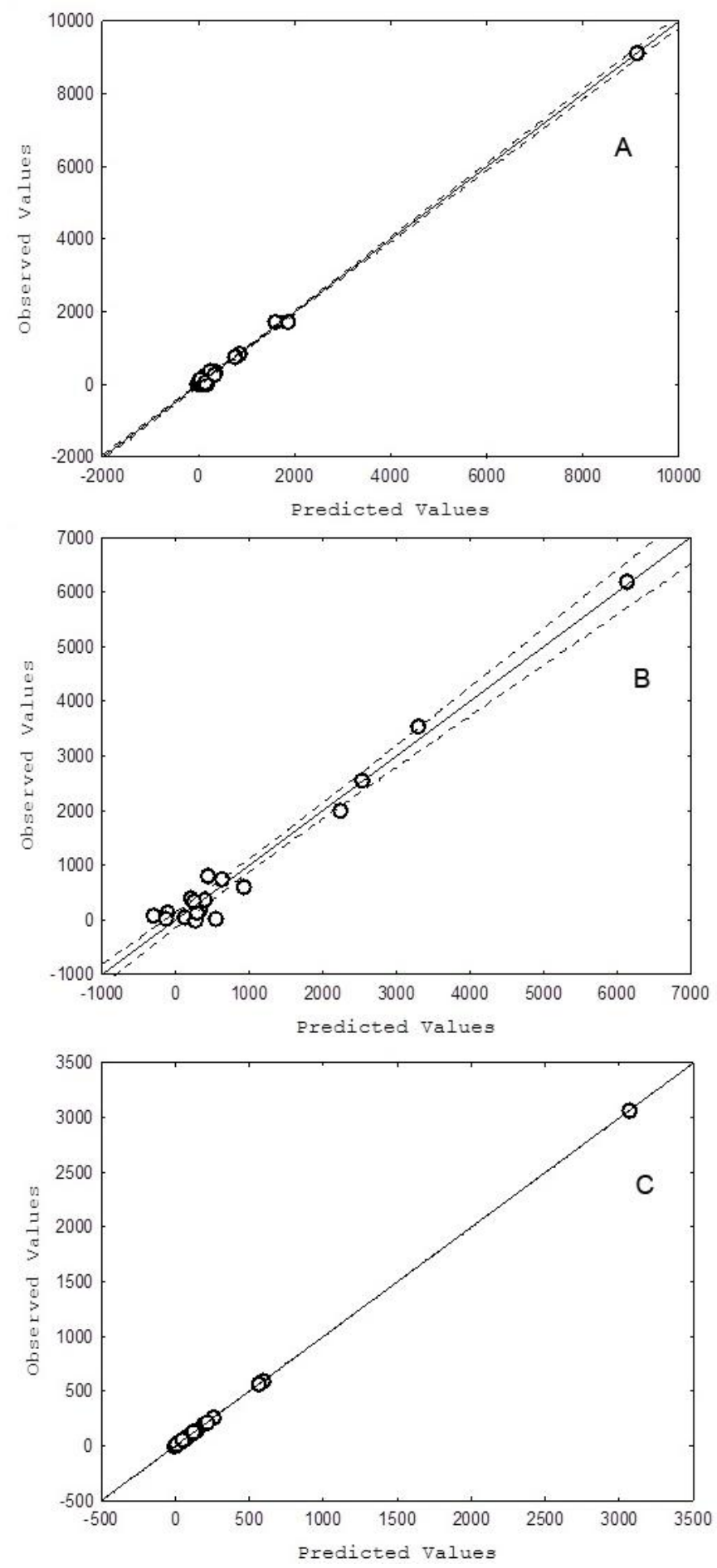

Figure 11. Regression models relating the number of the groups of zooplankton with environmental factors for 2013:

A: Copepoda $=0.014 S_{\text {cat }}-2114 \mathrm{pH}-30.15 \mathrm{SO}_{4}-1679 \mathrm{Zn}-11.11 \mathrm{~L}+143.54 \mathrm{Sh}_{\text {wetl }}+2.78 \mathrm{~W}_{\mathrm{fl}}$ $+128.91(\mathrm{Na}+\mathrm{K})+3.44 \mathrm{Al}-2327 \mathrm{~N}_{\text {tot }}+29.04 \mathrm{COD}+8.32 P_{\text {tot }}+16927$ (September. $\left.R^{2}=0.9959\right) ; \mathrm{B}:$ Cladocera $=5.16 W_{f l}-0.05 S_{\text {cat }}+84.66 \mathrm{Cl}+1.29 \mathrm{Fe}-441 \mathrm{Chl}-289 \mathrm{Sh}_{\text {lakes }}-193(\mathrm{Na}+\mathrm{K})-12.07 P_{\text {tot }}{ }^{-}$ $305 B G A+1.34 A l+5283\left(\right.$ June. $\left.R^{2}=0.9487\right) ; C:$ Rotifera $=14718 P b$

$33.84 \mathrm{TOC}+494 \mathrm{Zn}+1.77 \mathrm{~L}+51 \mathrm{Sh}_{\text {wet }}+61 \mathrm{Cl}+97 \mathrm{Chl}-202 \mathrm{Ca}+288 \mathrm{Mg}-$

$0.34 \mathrm{Fe}+39.88 \mathrm{SO}_{4}+25.57 \mathrm{Sh}_{\text {lakes }}+180 \mathrm{pH}+0.14 \mathrm{Al}+93 \mathrm{Cu}+0.004 \mathrm{~S}_{\text {cat }}+3.52 P_{\text {tot }}+233 \mathrm{TDS}-10168$ (September . $\left.R^{2}=0.9999\right)$. 

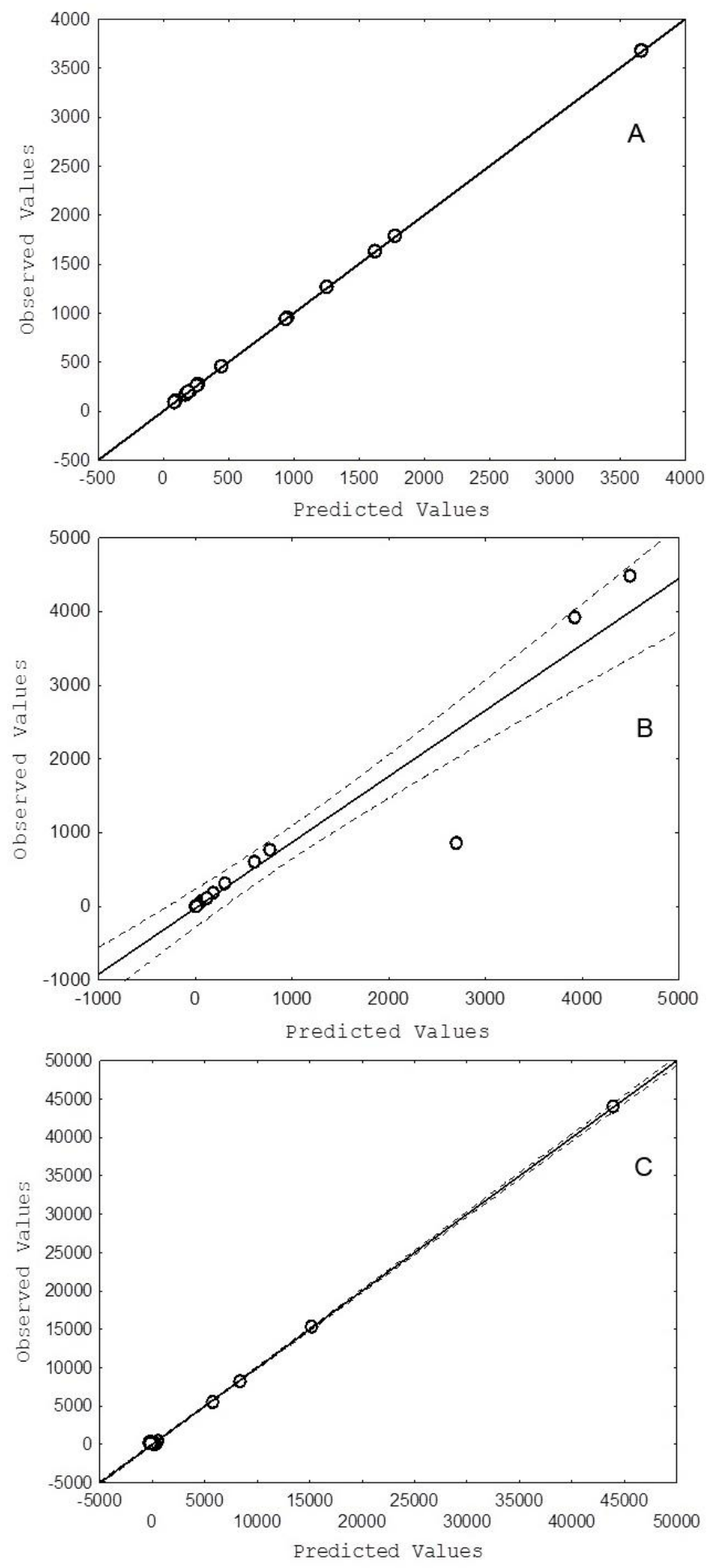

Figure 12. Regression models relating the number of the groups of zooplankton with environmental factors for 2014:

A: Copepoda $=4382 \mathrm{NH}_{4}+24.28 \mathrm{NTU}-336 \mathrm{Mg}+1327 \mathrm{pH}+914 \mathrm{~Pb}-0.03 \mathrm{~S}_{\text {cat }}+3.27 \mathrm{Wfl}_{\mathrm{fl}}$

4.39L+4.04W $W_{\text {col }}+6.05 \mathrm{Mn}-814 \mathrm{~N}_{\text {tot }}-103 \mathrm{NO}_{3}+44.36(\mathrm{Na}+\mathrm{K})-29.51 \mathrm{BOD}_{5^{-}}-0.08 \mathrm{P}_{\text {tot }}-9283\left(\mathrm{May} . \mathrm{R}^{2}=1.0000\right)$;

B: Cladocera $=24 \mathrm{~W}_{\text {col }}-0.05 \mathrm{~S}_{\text {cat }}+4.97 \mathrm{~W}_{\mathrm{fl}}-10452 \mathrm{NH}_{4}-1097 \mathrm{NO}_{3}+51 P_{\text {min }}-47 P_{\text {tot }}+25381 \mathrm{Carb}+2543 \mathrm{Cl}$ -

163TOC-14NTU-6.6HCO $3+215 \mathrm{BOD}_{5}-71 \mathrm{Cu}+859$ (May. $\left.\mathrm{R}^{2}=0.9999\right)$; $\mathrm{C}:$ Rotifera $=3207(\mathrm{Na}+\mathrm{K})-$

$15304 \mathrm{Cl}+3648 \mathrm{SO}_{4}+765 \mathrm{Sh}_{\text {lakes }}+787 \mathrm{P}_{\text {min }}-240 P_{\text {tot }}-64 \mathrm{Mn}+42.33 \mathrm{~W}_{\text {col }}+3370 \mathrm{NO}_{3}-12379 \mathrm{BOD}_{5}+253198 \mathrm{TDS}$ -

26794Pb-28129 (July. $\left.R^{2}=0.9966\right)$. 
Table 4 shows the most common predictors of 9 regression equations for each of the groups of Copepoda, Rotifera, and Cladocera. The most common predictors of the regression equation for the Rotifera number were the catchment basin area, the lake percentage of the catchment basin ( 6 cases each), the content of sulphates, chlorides, and lead ( 5 cases each). The following predictors were considered significant $(p<0.05)$ : the catchment basin area (6 cases), the lake percentage of the catchment basin, the sulphates content $(5$ cases $)$. Common and significant $(\mathrm{p}<0.05)$ predictors for the numbers of Cladocera zooplankters included the catchment basin area (5 cases) and the river discharge (4 cases). The content of chlorides and copper were included in the regression equations at the rate of 4 . The numbers of Copepoda crustaceans were determined by such parameters of the regression equations as water discharge and the catchment basin area, found at the rate of 6 . They were significant $(\mathrm{p}<0.05)$ in 6 and 5 cases respectively. The regression equations included such variables as the area of wetlands within the catchment basin, the length of the river and some chemical parameters: content of metals (aluminium, copper and iron), $\mathrm{pH}$, total dissolved solids, content of certain ions $\left(\mathrm{Na}+\mathrm{K}, \mathrm{NH}_{4}{ }^{+}, \mathrm{Mg}^{2+}\right)$, total carbon and total phosphorus, such physical parameters as turbidity and water colour (Table 4).

Table 4. The frequency of inclusion of a predictor in a regression equations (F1) for determining the number of Rotifera, Cladocera, Copepoda and frequency of predictor as significant $(p<0.05)(F 2)$.

\begin{tabular}{|c|c|c|c|c|c|c|}
\hline \multirow{2}{*}{ Predictor } & \multicolumn{2}{|c|}{ Rotifera } & \multicolumn{2}{|c|}{ Cladocera } & \multicolumn{2}{|c|}{ Copepoda } \\
\hline & F1 & F2 & F1 & F2 & F1 & F2 \\
\hline $\mathrm{S}_{\text {cat }}, \mathrm{km}^{2}$ & 6 & 6 & 5 & 5 & 6 & 5 \\
\hline $\mathrm{Sh}_{\text {lakes }}, \%$ & 6 & 5 & $-\ll-$ & $-\ll-$ & 3 & 3 \\
\hline $\mathrm{Sh}_{\text {wetl }}, \%$ & $-\ll-$ & $-\ll-$ & $-\ll-$ & $-\ll-$ & 4 & 4 \\
\hline $\mathrm{SO}_{4}{ }^{2-}, \mathrm{mg} / \mathrm{l}$ & 5 & 5 & $-\ll-$ & $-\ll-$ & 4 & 2 \\
\hline $\mathrm{W}_{\mathrm{fl}}, \mathrm{m}^{3} / \mathrm{s}$ & 3 & 2 & 4 & 4 & 6 & 6 \\
\hline $\mathrm{Cl}^{\prime}, \mathrm{mg} / \mathrm{l}$ & 5 & 4 & 4 & 2 & 3 & 2 \\
\hline $\mathrm{Pb}, \mu \mathrm{g} / \mathrm{l}$ & 5 & 2 & $-\ll-$ & $-\ll-$ & 3 & 1 \\
\hline Chl, $\mu \mathrm{g} / \mathrm{l}$ & 4 & 4 & $-\ll-$ & $-\ll-$ & $-\ll-$ & $-\ll-$ \\
\hline $\mathrm{Al}, \mu \mathrm{g} / \mathrm{l}$ & 3 & 3 & 3 & 3 & $-\ll-$ & $-\ll-$ \\
\hline TDS, g/l & 4 & 4 & $-\ll-$ & $-\ll-$ & $-\ll-$ & $-\ll-$ \\
\hline $\mathrm{L}, \mathrm{km}$ & 4 & 4 & $-\ll-$ & $-\ll-$ & 4 & 3 \\
\hline $\mathrm{P}_{\mathrm{tot}}, \mathrm{mg} / \mathrm{l}$ & 4 & 3 & $-\ll-$ & $-\ll-$ & 4 & 4 \\
\hline $\mathrm{Cu}, \mu \mathrm{g} / \mathrm{l}$ & 4 & 2 & 4 & 2 & $-\ll-$ & $-\ll-$ \\
\hline $\mathrm{W}_{\mathrm{col}}$, degrees. & 3 & 1 & 3 & 3 & 3 & 1 \\
\hline $\mathrm{Na}+\mathrm{K}, \mu \mathrm{g} / \mathrm{l}$ & 3 & 3 & 3 & 2 & 3 & 3 \\
\hline $\mathrm{NH}_{4}{ }^{+}, \mathrm{mg} / \mathrm{l}$ & 3 & 3 & $-\ll-$ & $-\ll-$ & $-\ll-$ & $-\ll-$ \\
\hline $\mathrm{Fe}, \mu \mathrm{g} / \mathrm{l}$ & 3 & 2 & $-\ll-$ & $-\ll-$ & 3 & 2 \\
\hline $\mathrm{pH}$ & 3 & 2 & $-\ll-$ & $-\ll-$ & 4 & 2 \\
\hline Turbidity, NTU & $-\ll-$ & $-\ll-$ & 3 & 3 & $-\ll-$ & $-\ll-$ \\
\hline $\mathrm{TOC}, \mathrm{mgC} / \mathrm{l}$ & $-\ll-$ & $-\ll-$ & $-\ll-$ & $-\ll-$ & 3 & 3 \\
\hline $\mathrm{Mg}^{2+}, \mu \mathrm{g} / \mathrm{l}$ & $-\ll-$ & $-\ll-$ & $-\ll-$ & $-\ll-$ & 3 & 2 \\
\hline
\end{tabular}

$-\ll--$ non-inclusion of predictor. 


\section{Discussion}

The study performed in 2011-2014 showed that taxonomic composition of the zooplankton community of the rivers of Lake Ladoga local catchment basin and the Neva River was common to the fauna of water bodies of the European North (Kulikova, 2012; Ryabinkina et al., 2012) and was mostly cosmopolitan. The total list of species composition of the zooplankton communities of the studied watercourses, as well as the species richness of most rivers were formed by Cladocera. Rotifers predominated only in two rivers - the Kokkolan and the Burnaya. Virtually all species (99\%) were found in Lake Ladoga (Rodionova, 2011). The dominant complex of the river zooplankton communities was formed by the members of lake and littoral macrophyte complexe, due to high lake percentage within the areas of the catchment basins of the studied rivers (up to 14\%). Biogeographic analysis shows that it is eurythermic and moderately warm-water species that prevailed in the integrated zooplankton complex of the lake tributaries.

Despite the fact that quantitative parameters of the Ladoga tributaries considerably varied between the stations during the study period, major trends of the zooplankton community development in different seasons can be described. In spring, the number and biomass of zooplankton of large rivers (Svir, Vuoksa, Burnaya, Volkhov, Syas) were essentially formed by the members of Rotifera, while in other tributaries - by copepods, mostly juvenile. In summer, the number of zooplankton in most communities consisted of Copepoda (Cyclopoida) and Cladocera crustaceans, and the biomass - of Copepoda (Cyclopoida and Calanoida) only. In autumn, all the groups of zooplanktons prevailed in numbers in different rivers and in different proportions, but the biomass was essentially determined by the members of Cladocera. The major trends in seasonal changes of the community of crustaceans and rotifers observed at the stations of study were common for lotic communities (Czerniawski et al., 2013; Gromova et al., 2013).

Quantitative parameters of the zooplankton development considerably varied between different stations and different seasons, but the mean values over the period were low, which is typical for the watercourses of the region. The highest values of number and biomass were observed at the station at the Neva River head. Figures 2 and 3 show that in most rivers mean values of number and biomass of Cladocera crustaceans were higher than mean quantitative parameters of the development of Rotifera and Copepoda zooplanktons. A regular pattern of decrease in quantitative parameters of the zooplankton development in the rivers with smaller catchment basin areas can also be noted (Figs. 2, $3)$. The only exception were low number and biomass at the lower course of a large tributary - the Volkhov River. The zooplankton community of the river mouth can probably be depressed by the Volkhov hydroelectric plant.

The results of the statistical analysis of the data we have performed show that, in case of river clustering based on the species composition and abundance, similar clusters in different seasons of the same year or in different years are almost never formed.

Virtually absent regular patterns in river clustering based on the number of individual zooplankton species and discrepancy in the obtained river clusters and the clusters of similar rivers, based on the physic-chemical parameters and the catchment basins features, indicate high variance and unpredictability of the development of individual species within the Lake Ladoga tributaries.

The results of regression and correlation analyses did not show significant $(p<0.05)$ relationship between the parameters of the development of individual zooplankton species and the assessed parameters of water of the Lake Ladoga tributaries. 
Such results prove that abiotic factors and physiographic characteristics of the rivers catchment basins certainly influence the zooplankton in the general way, but apparently the actual structure of community and the populations of individual zooplankton species of the Lake Ladoga tributaries are to a greater extent determined by other factors that were not considered in current study.

Perhaps, these factors include such hydrological parameters as the current speed, the width and depth of rivers, which, according to the concept of river continuum, have great impact on the species composition, the trophic structure, and the distribution of hydrobiont communities (Vannote et al., 1980). The possible influence of the trophic state of the lakes that give rise to rivers and biotic interactions in the water courses on the development of zooplankton communities, should not be excluded, too (Krylov et al., 2007; Czerniawski and Domagała, 2010; Krylov et al., 2011; Chaparro et al., 2015).

Similar results were obtained in case of 54 small water bodies of Wisconsin (USA), showing that the number of species and distribution of spring zooplankton communities were not correlated with physiographic features, $\mathrm{pH}$, electric conductivity, total phosphorus, nitrogen, ions of calcium, sulphates, nitrates, chlorides and silicates (Schell et al., 2001).

In our study, we considered both individual factors that directly influence biota and such integrated variables as catchment basin area, area of wetlands, lake percentage of the catchment basin, etc. These integrated factors virtually determine the parameters considered in our study and the environmental factors that have not been defined and measured. It gives reason to the fact that these integral variables turned out to be the most significant ones and most commonly included in the regression models we obtained (Table 4). We did not manage to discover consistent correlations with any of studied parameters of water of the Lake Ladoga tributaries for individual zooplankton species. At the next stage we tried to reveal any possible association between the parameters of the environment and total abundances of Copepoda, Cladocera, and Rotifera groups. We performed multiple forward stepwise regression analysis involving 37 above-listed abiotic parameters at the first stage. The data shown in Table 4 prove that the integral factors (catchment basin area, water discharge, and lake percentage) are the most significant ones and most often included in the regression equations of the number of Copepoda, Rotifera, and Cladocera.

In earlier studies of the phytoplankton inhabiting the Lake Ladoga tributaries, the dependence of quantitative patterns of the community development on the lake percentage within the rivers catchment basins has also been revealed (Trifonova (ed.), 2006).

The dependence of the structure of plankton communities on the integrated parameters rather than on individual physic-chemical parameters has been shown for different types of aquatic ecosystems. The study of the impact of environmental factors on the zooplankton of lowland rivers of Central Russia has shown that the results of man-induced and zoogenic environmental influence are manifested in different ways, depending on many natural factors, especially hydrological ones (Krylov, 2002a, 2002b). Mechanism of effect of hydrological factors on zooplankton structure and quantitative parameters as element of the lotic ecosystems was shown in (Gromova et al., 2013). The abundance of potamoplankton in the Vistula River (Poland) is also determined by hydrological conditions (Napiórkowski and Napiórkowska, 2013). The variation of water level and the flow pattern are the most important factors of structure and life of alluvial river ecosystems (Junk et al., 1989; Neiff, 1990; Tockner et al., 2000a, 2000b; Bozelli et al., 2015). 
The results of the study of planktonic crustaceans in the reservoir cascade in Brazil indicate that the water residence time (WRT) and such morphometric features of reservoirs as their size, depth, and shape, have a considerable impact on the structure and functioning of zooplankton communities (Bini et al., 2008; Perbiche-Neves and Nogueira, 2010, 2013).

The analysis of the data on the community of crustaceans and rotifers in the regulated Oder River revealed that the most important factor that determines the condition of zooplankton and the physic-chemical properties is WRT (Czerniawski et al., 2013). The influence of hydrochemical factors on the zooplankton of the Novosibirsk reservoir is also connected to the peculiarities of hydrological regime in the parts of the water body (Dvurechenskaya and Yermolaeva, 2014). Zooplankton of 20 lakes of Kejimkujik National Park (Canada) was strongly correlated with such factor as elevation, but not with the studied hydrochemical parameters (Bowman et al., 2014). Only the differences in hydrological and geomorphological conditions led to structural and functional differences in the planktonic communities of the semiarid Macquarie Marshes (Australia) (Kobayashi et al., 2015).

Content of $\mathrm{Mg}^{2+}, \mathrm{Na}^{+}+\mathrm{K}^{+}$ions and such metals as $\mathrm{Pb}, \mathrm{Fe}, \mathrm{Cu}, \mathrm{Al}$ were included in the regression equations less frequently (Table 4). It is well-known that depending on chemical and physical speciation, metals can enter the zooplankters in different ways; for instance, dissolved metals can come directly from water, while the particles of associated metals can be consumed with food (Sofyan et al., 2006). Thus, they have different impact on the short-term and long-term changes in structure and composition of the zooplankton community (De Paiva Magalhães et al., 2015). Unfortunately, we have no data on the form of metals present in the water of the tributaries and on their bioavailability for the organisms during the period of our study.

Total phosphorus content was often (up to 4 cases out of 9) included in our multiple regression equations describing total numbers of Copepoda and Rotifera (Table 4). Considering low natural concentrations of biogenic elements, especially phosphorus, in the catchment basin of Lake Ladoga (Appendix A), one might assume that the concentration of biogenic elements in rivers is the limiting factor for zooplankton, influencing the primary production of phytoplankton. Similar results were obtained for the rivers in Shanghai (China), where population figures and structure of the zooplankton community depended on the content of another biogenic element - total nitrogen, whose concentrations were 20 times lower than those of total phosphorus (Na et al., 2014).

It is interesting that there are many studies describing positive correlation between qualitative patterns of the zooplankton development and water temperature (for instance, in such large rivers as the Danube (Hungary), the Oder (NW Poland)) (Vadadi-Fülöp et al., 2009; Czerniawski et al., 2013), or between it and electric conductivity. However, according to the results of our study, these variables were not included in the equations linking the abundance of zooplankton groups in the Lake Ladoga tributaries and in the Neva River to the environmental factors.

\section{Conclusions}

A total of 137 zooplankton taxa ranking below genus were identified in 19 tributaries of Lake Ladoga and the Neva River head in 2011-2014, including 56 species and subspecies of Rotifera (40.9\%), 57 - of Cladocera (41.6\%), 24 - of Copepoda (17.5\%). Quantitative parameters of zooplankton varied in different rivers, still mean values of 
numbers (30-9580 ind. $\left./ \mathrm{m}^{3}\right)$ and biomass $\left(0.17-266.2 \mathrm{mg} / \mathrm{m}^{3}\right)$ were low. The members of Copepoda and Rotifera were dominant in the lake tributaries in spring, Cladocera - in summer, Cladocera and Copepoda - in autumn.

The development patterns of individual zooplankton species of Copepoda, Cladocera, Rotifera in tributaries of Lake Ladoga was proven to be stochastic. Species composition and patterns of qualitative development cannot be linked to any environmental factors or their combination. It is impossible to identify groups of tributaries of Lake Ladoga with similar patterns of zooplankton development basing on the composition and numbers of individual zooplankton species.

River clustering based on hydrochemical, hydrological parameters and catchment basins' features provides an opportunity to distinguish groups of similar rivers that were consistently formed during different years and seasons. Groups of similar rivers were isolated according to their physiographic position. The cases of belonging of some rivers to different clusters in different time periods turned out to be rare.

Total abundances of Copepoda, Cladocera, and Rotifera in the tributaries of Lake Ladoga are consistently linked with certain combinations of studied physiographic parameters and features of the aquatic habitat, which was proved by the possibility to develop highly significant regression models, describing the number of zooplankton groups as a function of a certain set of variables. Integrated physiographic factors, like the catchment basin area, water discharge, and lake percentage of the catchment basin, are the most important in the level of qualitative development of Copepoda, Rotifera, and Cladocera in tributaries of Lake Ladoga.

Acknowledgements. The authors are thankful to M. O. Dudakov and I. A. Sotnikov for assistance in sampling. We are grateful to N. V. Rodionova, N. V. Polyakova, A. A. Kotov, and A. Y. Sinev for their help in the taxonomic analysis of zooplankton. We are grateful to the Environmental Safety Observatory Resource Centre of St. Petersburg State University for the technical support for this study as well.

\section{REFERENCES}

[1] Abakumov, V. A. (ed.) (1992): Rukovodstvo po gidrobiologicheskomu monitoringu presnovodnykh ekosistem [Guide to hydrobiological monitoring of freshwater ecosystems]. - Hydrometeoizdat, St. Petersburg. (In Russian).

[2] Alekin, O. A. (1953): Osnovy gidrokhimii [Fundamentals of hydrochemistry]. Hydrometeoizdat, Leningrad (In Russian).

[3] Alekseev, V. R., Tsalolikhin, S. J. (eds.). (2010): Opredelitel zooplanktona i zoobentosa presnykh vod Yevropeyskoy Rossii [The key of zooplankton and zoobenthos of freshwater European Russia], Vol.1. Zooplankton. - KMK, Moscow. (In Russian).

[4] Aleshina, D., Kurashov, E., Rodionova, N., Guseva, M. (2014): Sovremennoe sostojanie vesennego zooplanktona pritokov Ladozhskogo ozera [The current state of the spring zooplankton in the tributaries of Lake Ladoga]. - Water: chemistry and ecology 4: 64-71. (In Russian).

[5] Andronikova, I. N. (1996): Zooplankton characteristics in monitoring of Lake Ladoga. Hydrobiologia $322: 173-179$.

[6] Balushkina, E. B., Vinberg, G. G. (1979): Zavisimost mezhdu dlinoy i massoy tela planktonnykh rakoobraznykh [Relationship between zooplanktonic crustaceans' length and body weight]. - In: Vinberg, G. G. (ed.) Eksperimentalnye i polevye issledovaniya biologicheskikh osnov produktivnosti ozer [Experimental and field studies of the productivity in the lakes], Nauka, Leningrad. (In Russian). 
[7] Bini, L. M., Da Silva, L. C. F., Velho, L. F. M., Bonecker, C. C., Lansac-Tôha, F. A. (2008): Zooplankton assemblage concordance patterns in Brazilian reservoirs. Hydrobiologia 598: 247-255.

[8] Bowman, M. F., Nussbaumer, C., Burgess N. M. (2014): Community composition of lake zooplankton, benthic macroinvertebrates and forage fish across a $\mathrm{pH}$ gradient in Kejimkujik National Park, Nova Scotia, Canada. - Water, Air, \& Soil Pollution 225: 2211. DOI: 10.1007/s11270-014-2211-7.

[9] Bozelli, R. L., Thomaz, S. M., Padial, A. A., Lopes, P. M., Bini, L. M. (2015): Floods decrease zooplankton beta diversity and environmental heterogeneity in an Amazonian floodplain system. - Hydrobiologia 753: 233-241.

[10] Chaparro, G., Fontanarrosa, M. S., Cataldo, D., O’Farrell, I. (2015): Hydrology driven factors might weaken fish predation effects on zooplankton structure in a vegetated warm temperate floodplain lake. - Hydrobiologia 752: 187-202.

[11] Czerniawski, R., Domagała, J. (2010): Similarities in zooplankton community between River Drawa and its two tributaries (Polish part of River Odra). - Hydrobiologia 638: 137-149.

[12] Czerniawski, R., Pilecka-Rapacz, M., Domagała, J. (2013): Zooplankton communities of inter-connected sections of lower River Oder (NW Poland). - Central European Journal of Biology 8: 18-29.

[13] De Paiva Magalhães, D., Da Costa, M. M. R., Baptista, D. F., Buss, D. F. (2015): Metal bioavailability and toxicity in freshwaters. - Environmental Chemistry Letters 13: 69-87. DOI: 10.1007/s10311-015-0491-9.

[14] Dvurechenskaya, S. Y., Yermolaeva, N. I. (2014): Interrelations between chemical composition of water and characteristics of zooplankton in the Novosibirsk reservoir. Contemporary Problems of Ecology 7: 465-473.

[15] Ejsmont-Karabin, J. Gorelysheva, Z. Kalinowska, K., Weglenska, T. (2004): Role of zooplankton (Ciliata, Rotifera and Crustacea) in phosphorus removal from cycling: lakes of the river Jorka watershed (Masuria Lakeland, Poland). - Polish Journal of Ecology 52: 275-284.

[16] Gromova, Yu. F., Afanasyev, S. A., Shevtsova, L. V. (2013): Structural organization of zooplankton in transformed small rivers. - Hydrobiological Journal 49: 21-29. DOI: 10.1615/HydrobJ.v49.i1.

[17] Junk, W. J., Bayley, P. B., Sparks, R. E. (1989): The flood pulse concept in riverfloodplain systems. - Canadian Special Publication of Fisheries and Aquatic Sciences 106: 110-127.

[18] Kobayashi, T., Ralph, T. J., Ryder, D. S., Hunter, S. J., Shiel, R. J., Segers, H. (2015): Spatial dissimilarities in plankton structure and function during flood pulses in a semiarid floodplain wetland system. - Hydrobiologia 747: 19-31.

[19] Kondratyev, S., Trumbull, N. (2012): Nutrient loading on the eastern Gulf of Finland (Baltic sea) from the Russian catchment area. - Journal of Hydrology and Hydromechanics 60: 145-151.

[20] Korovchinsky, N. M. (2000): Species richness of pelagic Cladocera of large lakes in the eastern hemisphere. - Hydrobiologia 434: 41-54.

[21] Krylov, A. V. (2002a): Izmenenie strukturnoy organizatsii zooplanktona maloy reki v usloviyakh razlichnoy protochnosti [The change of the structural organization of zooplankton in small rivers in different flowage]. - Inland water biology 2: 51-54. (In Russian).

[22] Krylov, A. V. (2002b): Activity of beavers as an ecological factor affecting the zooplankton of small rivers. - Russian Journal of Ecology 33: 349-356.

[23] Krylov, A. V., Chalova, I. V., Tselmovich, O. L. (2007): Cladocerans under conditions of small river damming by man and beavers. - Russian Journal of Ecology 32: 34-38. 
[24] Krylov, A. V., Kulakov, D. V., Papchenkov, V. G. (2011): Effect of water-loving bird colonies on zooplankton in littoral zones of water bodies of different types. - Russian Journal of Ecology 6: 518-524.

[25] Kulikova, T. P. (2012): Zooplankton vodnykh obektov severnoy chasti basseyna Ladozhskogo ozera [Zooplankton in water bodies of the Northern part of the basin of Lake Ladoga]. - Karelian Research Centre of the Russian Academy of Sciences, Petrozavodsk. (In Russian).

[26] Kurashov, E. A., Telesh, I. V., Panov, V. E., Usenko, N. V., Rychkova, M. A. (1996): Invertebrate communities associated with macrophytes in Lake Ladoga: effects of environmental factors. - Hydrobiologia 322: 49-55.

[27] Kutikova, L. A. (1970): Kolovratki fauny SSSR [Rotifers of the USSR fauna]. - Fauna of the USSR Series 104, Nauka, Leningrad. (In Russian).

[28] Makartseva, E. S. (2004): Sostav i produktivnost zooplanktona Vuoksy [The composition and production of Vuoksa zooplankton]. - In: Trifonova, I. S. and Belyakov, V. P. (eds.), Sostoyanie biotsenozov ozerno-rechnoy sistemy Vuoksy [State biotic communities in Vuoksa system of lakes and rivers]. BBM, St. Petersburg. (In Russian).

[29] Na, Y., Erchao, L., Dexiang, F., Baicai, X., Chaoqun, W., Meiling, Z., Liqiao, C. (2014): Correlations between zooplankton assemblages and environmental factors in the downtown rivers of Shanghai, China. - Chinese Journal of Oceanology and Limnology 32: 1352-1363.

[30] Napiórkowski, P., Napiórkowska, T. (2013): The diversity and longitudinal changes of zooplankton in the lower course of a large, regulated European river (the lower Vistula River, Poland). - Biologia 68: 1163-1171.

[31] Neiff, J. J. (1990): Ideas para la interpretación ecológica del Paraná. - Interciencia 15: 424-441.

[32] Perbiche-Neves, G., Nogueira, M. G. (2010): Multidimensional effects on cladoceran (Crustacea, Anomopoda) assemblages in two cascade reservoirs (SE - Brazil). - Lakes and Reservoirs: Research and Management 15: 151-164.

[33] Perbiche-Neves, G., Nogueira, M. G. (2013): Reservoir design and operation: effects on aquatic biota-a case study of planktonic copepods. - Hydrobiologia 707: 187-198.

[34] Pesenko, Y. A. (1982): Printsipy i metody kolichestvennogo analiza v faunisticheskikh issledovaniyakh [Principles and methods of quantitative analysis in faunistic studies]. Nauka, Moscow. (In Russian).

[35] Rodionova, N. V. (2011): O vidovom sostave zooplanktona litorali Ladozhskogo ozera [On the species composition of zooplankton of the littoral of Lake Ladoga]. - In: Kurashov, E. A. (ed.) Litoralnaya zona Ladozhskogo ozera [Littoral zone of Lake Ladoga]. Nestor-Istoriya, St. Petersburg. (In Russian).

[36] Ruttner-Kolisko, A. (1977): Suggestions for biomass calculation of plankton rotifers. Archiv für Hydrobiologie Beiheft Ergebnisse der Limnologie 8: 71-76.

[37] Ryabinkina, M. G., Kulikova T. P., Ryzhkov, L. P. (2012): Zooplankton vodoemov basseyna severnoy Ladogi [Zooplankton in the northern Lake Ladoga catchment]. Trudy Karelskogo nauchnogo tsentra RAN 1: 113-125. (In Russian)

[38] Rylov, V. M. (1963): Freshwater Cyclopoida. - IPST cat. no. 839, Israel Program for Scientific Translations, Jerusalem.

[39] Ryzhkov, L. P. (1999): Ozera basseyna severnoy Ladogi [Lakes in the basin of north Lake Ladoga]. - Petrozavodsk University Press, Petrozavodsk. (In Russian).

[40] Schell, J. M., Santos-Flores, C. J., Allen, P. E., Hunker, B. M., Kloehn, S., Michelson, A., Lillie, R. A., Dodson, S. I. (2001): Physical-chemical influences on vernal zooplankton community structure in small lakes and wetlands of Wisconsin, U. S. A. - Hydrobiologia 445: 37-50.

[41] Semenov, A.D. (ed.). (1977): Rukovodstvo po khimicheskomu analizu poverkhnostnykh vod sushi [Manual on chemical analysis of surface waters]. - Gidrometeoizdat, Leningrad. (In Russian). 
[42] Shannon, C. E. (1948): The mathematical theory of communication. - Bell System Technical Journal 27: 379-423.

[43] Sofyan, A., Shaw, J. R., Birge, W. J. (2006): Metal trophic transfer from algae to cladocerans and the relative importance of dietary metal exposure. - Environmental Toxicology and Chemistry 25: 1034-1041.

[44] Telesh, I. V. (1996): Species composition of planktonic Rotifera, Cladocera and Copepoda in the littoral zone of Lake Ladoga. - Hydrobiologia 322: 181-185.

[45] Thorp, J. H., Casper, A. F. (2002): Potential effects on zooplankton from species shifts in mussel planktivory: a field experiment in the St. Lawrence River. - Freshwater Biology 47: 107-119.

[46] Thorp, J. H., Casper, A. F. (2003): Importance of biotic interactions in large rivers: an experiment with planktivorous fish, dreissenid mussels, and zooplankton in the St. Lawrence. - River Research and Applications 19: 265-279.

[47] Thorp, J. H., Mantovani, S. (2005): Zooplankton of turbid and hydrologically dynamic. Freshwater Biology 50: 1474-1491.

[48] Tockner, K., Baumgartner, C., Schiemer, F., Ward, J. V. (2000a): Biodiversity of a Danubian floodplain: structural, functional and compositional aspects. - In: Gopal, B., Junk, W. J., Davis, J. A. (eds.) Biodiversity in wetlands: assessment, function and conservation. Backhuys Publishers, Leiden.

[49] Tockner, K., Malard, F., Ward, J. V. (2000b): An extension of the flood pulse concept. Hydrological Processes 14: 2861-2883.

[50] Trifonova, I. S. (ed.). (2006): Otsenka ekologicheskogo sostoyaniya rek basseyna Ladozhskogo ozera po gidrokhimicheskim pokazatelyam i strukture hydrobiotsenozov Evaluation of the ecological state of rivers in Lake Ladoga basin by hydrochemical indexes and structure of hydrobiocenoses]. - Lema, St. Petersburg. (In Russian).

[51] Trifonova, I. S., Pavlova, O. A. (2004): Assessment of the trophic state of Lake Ladoga tributaries and the Neva River by phytoplankton. - Water Resources 31: 679-688.

[52] Turschak, B. A., Moerke, A. H., Evans, B. I. (2011): Spatial and seasonal patterns in the crustacean zooplankton community of the St. Marys River. - Journal of Great Lakes Research 37: 21-27.

[53] Vadadi-Fülöp, C., Hufnagel, L., Jablonszky, G., Zsuga, K. (2009): Crustacean plankton abundance in the Danube River and its side arms in Hungary. - Biologia 64: 1184-1195.

[54] Vannote, R. L., Minshall, G. W., Cummins, K. W., Sedell, J. R., Cushing, C. E. (1980): The river continuum concept. - Canadian Journal of Fisheries and Aquatic Sciences 24: 277-304.

[55] Zhao, K., Song, K., Pan, Y., Wang, L., Da, L., Wang, Q. (2017): Metacommunity structure of zooplankton in river networks: Roles ofenvironmental and spatial factors. Ecological Indicators 73: 96-104. 


\section{APPENDIX}

Appendix A. Hydrochemical parameters in tributaries of Lake Ladoga and Neva river in 2011-2014: pH, turbidity (TDS, g/l), total phosphorus ( $P_{\text {tot }}$ $m g / l)$, total nitrogen $\left(N_{\text {tot }}, \mathrm{mg} / \mathrm{l}\right)$, sulphates $\left(\mathrm{SO}_{4}^{2-}, \mathrm{mg} / \mathrm{l}\right)$, carbonates $\left(\mathrm{HCO}_{3}^{-}, \mathrm{mg} / \mathrm{l}\right)$, chlorides $(\mathrm{Cl}, \mathrm{mg} / \mathrm{l})$.

\begin{tabular}{|c|c|c|c|c|c|c|c|c|}
\hline № & River & pH & TDS, g/l & $P_{\text {tot }}, \mathrm{mg} / \mathrm{l}$ & $\mathrm{N}_{\text {tot }}, \mathrm{mg} / \mathrm{l}$ & $\mathrm{SO}_{4}{ }^{2-}, \mathrm{mg} / \mathrm{l}$ & $\mathrm{HCO}_{3}{ }^{-}, \mathrm{mg} / \mathrm{l}$ & $\mathrm{Cl}^{-}, \mathrm{mg} / \mathrm{l}$ \\
\hline \multirow{2}{*}{1} & \multirow{2}{*}{ Neva } & 7,39(0,05) & $\underline{0,06(0,04)}$ & $0,022(0,36)$ & $\underline{0,59(0,05)}$ & $8,44(0,16)$ & $30,63(0,06)$ & $\underline{5,48(0,09)}$ \\
\hline & & $6,48-7,60$ & $0,06-0,07$ & $0,012-0,035$ & $0,56-0,64$ & $6,20-9,80$ & $29,30-35,39$ & $4,69-6,24$ \\
\hline 2 & Volkhov & $6,99-7,89$ & $0,09-0,15$ & $0,038-0,117$ & $0,81-1,26$ & $5,23-12,21$ & $65,17-88,86$ & $9,37-19,14$ \\
\hline 3 & Svir & $\underline{7,17(0,04)}$ & $\underline{0,04(0,15)}$ & $\underline{0,024(0,39)}$ & $\underline{0,70(0,12)}$ & $\underline{5,20(0,53)}$ & $\underline{21,42(0,51)}$ & $\underline{3,01(0,26)}$ \\
\hline \multirow{2}{*}{4} & \multirow{2}{*}{ Syas } & $\underline{7,40(0,04)}$ & $\underline{0,11(0,36)}$ & $\underline{0,058(0,24)}$ & $\underline{0,80(0,15)}$ & $\underline{7,31(0,58)}$ & $79,50(0,44)$ & $\underline{5,58(0,26)}$ \\
\hline & & $7,09-7,99$ & $0,07-0,20$ & $0,030-0,078$ & $0,56-0,83$ & $2,06-11,59$ & $48,81-155,50$ & $3,65-7,62$ \\
\hline \multirow{2}{*}{5} & \multirow{2}{*}{ Burnaya } & $\underline{7,07}(0,03)$ & $\underline{0,05(0,06)}$ & $\underline{0,017(0,67)}$ & $\underline{0,57(0,14)}$ & $10,72(0,33)$ & $14,34(0,08)$ & $4,03(0,16)$ \\
\hline & & $6,63-7,50$ & $0,04-0,05$ & $0,015-0,068$ & $0,49-0,69$ & $6,63-15,30$ & $12,82-16,35$ & $3,22-5,28$ \\
\hline \multirow{2}{*}{6} & \multirow{2}{*}{ Vuoksa } & $\underline{7,09(0,03)}$ & $\underline{0,04(0,15)}$ & $\underline{24,9(0,67)}$ & $\underline{0,69(0,05)}$ & $\underline{6,32(0,11)}$ & $\underline{20,11(0,11)}$ & $\underline{3,57(0,38)}$ \\
\hline & & $6,84-7,57$ & $0,04-0,06$ & $0,020-0,089$ & $0,66-0,76$ & $5,23-7,00$ & $17,82-24,64$ & $2,41-6,70$ \\
\hline \multirow{2}{*}{7} & \multirow{2}{*}{ Pasha } & $\underline{6,90(0,05)}$ & $\underline{0,05(0,41)}$ & $\underline{0,044(0,43)}$ & $\underline{0,75(0,18)}$ & $\underline{3,89(0,62)}$ & $\underline{43,94(0,56)}$ & $\underline{3,34(0,54)}$ \\
\hline & & $6,66-7,61$ & $0,04-0,11$ & $0,024-0,078$ & $0,52-0,89$ & $1,92-10,08$ & $20,74-92,50$ & $1,31-6,95$ \\
\hline \multirow{2}{*}{8} & \multirow{2}{*}{ Oyat } & $\underline{6,99(0,05)}$ & $\underline{0,04(0,51)}$ & $\underline{0,048(0,20)}$ & $\underline{0,64(0,13)}$ & $\underline{3,89(0,48)}$ & $\underline{35,07(0,64)}$ & $\underline{2,44}(0,47)$ \\
\hline & & $6,48-7,56$ & $0,03-0,10$ & $0,026-0,057$ & $0,48-0,67$ & $1,92-7,01$ & $13,91-84,22$ & $1,23-4,47$ \\
\hline \multirow{2}{*}{9} & \multirow{2}{*}{ Yanis } & $\underline{6,73(0,03)}$ & $\underline{0,03(0,09)}$ & $\underline{0,018(0,57)}$ & $\underline{0,62(0,17)}$ & $\underline{5,22(0,10)}$ & $\underline{6,71(0,20)}$ & $\underline{1,97(0,43)}$ \\
\hline & & $6,38-6,87$ & $0,02-0,03$ & $0,011-0,052$ & $0,56-0,81$ & $4,85-6,40$ & $5,37-9,76$ & $1,42-3,83$ \\
\hline
\end{tabular}




\begin{tabular}{|c|c|c|c|c|c|c|c|c|}
\hline № & River & $\mathbf{p H}$ & TDS, g/l & $P_{\text {tot }}, \mathrm{mg} / \mathrm{l}$ & $\mathrm{N}_{\text {tot }}, \mathrm{mg} / \mathrm{l}$ & $\mathrm{SO}_{4}{ }^{2-}, \mathrm{mg} / \mathrm{l}$ & $\mathrm{HCO}_{3}^{-}, \mathrm{mg} / \mathrm{l}$ & $\mathrm{Cl}^{-}, \mathrm{mg} / \mathrm{l}$ \\
\hline \multirow{2}{*}{10} & \multirow{2}{*}{ Olonka } & $\underline{6,60(0,05)}$ & $\underline{0,04(0,28)}$ & $\underline{96,0(0,24)}$ & $\underline{0,74(0,18)}$ & $\underline{3,10(0,39)}$ & $\underline{18,86(0,47)}$ & $\underline{4,47(0,44)}$ \\
\hline & & $6,27-7,20$ & $0,03-0,06$ & $0,064-0,131$ & $0,54-0,87$ & $2,16-6,10$ & $9,30-33,19$ & $2,19-8,54$ \\
\hline \multirow{2}{*}{11} & \multirow{2}{*}{ Tulema } & $\underline{6,75(0,04)}$ & $\underline{0,02(0,41)}$ & $\underline{0,028(0,78)}$ & $\underline{0,73(0,23)}$ & $\underline{2,75(0,45)}$ & $\underline{9,28(0,48)}$ & $\underline{1,83(0,46)}$ \\
\hline & & $6,11-7,05$ & $0,02-0,05$ & $0,012-0,099$ & $0,48-0,95$ & $1,92-6,40$ & $3,60-19,28$ & $1,37-3,76$ \\
\hline \multirow{2}{*}{12} & \multirow{2}{*}{ Tohma } & $\underline{6,76(0,04)}$ & $\underline{0,05(0,12)}$ & $\underline{0,034(0,61)}$ & $\underline{0,78(0,05)}$ & $\underline{10,02(0,44)}$ & $\underline{17,09(0,29)}$ & $\underline{3,65(0,68)}$ \\
\hline & & $6,44-7,24$ & $0,04-0,05$ & $0,018-0,087$ & $0,73-0,80$ & $4,95-14,65$ & $11,22-25,14$ & $2,91-11,34$ \\
\hline \multirow{2}{*}{13} & \multirow{2}{*}{ Kokkalan } & $\underline{7,17(0,05)}$ & $\underline{0,05(0,28)}$ & $\underline{0,052(0,61)}$ & $\underline{0,66(0,06)}$ & $\underline{9,71(0,50)}$ & $\underline{22,89(0,35)}$ & $\underline{4,29(0,38)}$ \\
\hline & & $6,35-7,38$ & $0,03-0,07$ & $0,015-0,096$ & $0,63-0,71$ & $3,36-17,00$ & $9,76-31,00$ & $1,10-5,35$ \\
\hline \multirow{2}{*}{14} & \multirow{2}{*}{ Vidlitsa } & $\underline{6,94(0,03)}$ & $\underline{0,03(0,17)}$ & $\underline{0,044(0,27)}$ & $\underline{0,69(0,17)}$ & $\underline{3,01(0,39)}$ & $\underline{14,59(0,29)}$ & $\underline{2,22(0,44)}$ \\
\hline & & $6,54-7,19$ & $0,02-0,04$ & $0,028-0,058$ & $0,54-0,84$ & $2,36-6,10$ & $11,71-23,92$ & $1,37-4,40$ \\
\hline \multirow{2}{*}{15} & \multirow{2}{*}{ Uksun } & $\underline{6,40(0,05)}$ & $\underline{0,02(0,24)}$ & $\underline{0,018(0,91)}$ & $\underline{0,59(0,29)}$ & $\underline{2,74(0,28)}$ & $\underline{3,91(0,79)}$ & $\underline{1,58(0,65)}$ \\
\hline & & $5,95-6,82$ & $0,02-0,03$ & $0,012-0,076$ & $0,37-0,68$ & $1,82-3,80$ & $0,73-8,79$ & $1,03-4,54$ \\
\hline \multirow{2}{*}{16} & \multirow{2}{*}{ Tuloksa } & $\underline{6,60(0,07)}$ & $\underline{0,02(0,30)}$ & $\underline{0,086(0,23)}$ & $\underline{0,80(0,13)}$ & $\underline{2,79(0,37)}$ & $\underline{12,57(0,56)}$ & $\underline{2,04(0,39)}$ \\
\hline & & $5,81-7,20$ & $0,02-0,04$ & $0,065-0,121$ & $0,65-0,89$ & $1,56-4,90$ & $4,19-22,70$ & $1,37-4,08$ \\
\hline \multirow{2}{*}{17} & \multirow{2}{*}{ Lava } & $\underline{7,75(0,02)}$ & $\underline{0,17(0,21)}$ & $\underline{0,081(0,31)}$ & $\underline{1,74(0,27)}$ & $\underline{7,35(0,16)}$ & $\underline{134,37(0,17)}$ & $\underline{9,43(0,32)}$ \\
\hline & & $7,42-7,98$ & $0,15-0,26$ & $0,048-0,108$ & $1,10-1,94$ & $6,05-9,69$ & $121,79-185,93$ & $8,76-17,65$ \\
\hline \multirow{2}{*}{18} & \multirow{2}{*}{ Morje } & $\underline{6,59}(0,04)$ & $\underline{0,04(0,30)}$ & $\underline{0,136(0,30)}$ & $\underline{1,28(0,06)}$ & $\underline{4,95(0,29)}$ & $\underline{12,93(0,38)}$ & $\underline{5,82(0,21)}$ \\
\hline & & $5,97-6,75$ & $0,03-0,06$ & $0,078-0,186$ & $1,19-1,36$ & $2,55-7,51$ & $10,38-25,63$ & $4,04-7,62$ \\
\hline \multirow{2}{*}{19} & \multirow{2}{*}{ Avloga } & $\underline{7,06(0,04)}$ & $\underline{0,12(0,10)}$ & $\underline{0,293(0,30)}$ & $\underline{1,42(0,52)}$ & $\underline{12,27(0,23)}$ & $\underline{58,80(0,20)}$ & $\underline{10,89(0,12)}$ \\
\hline & & $6,90-7,57$ & $0,10-0,14$ & $0,180-0,482$ & $0,91-3,12$ & $7,31-14,36$ & $35,40-70,55$ & $9,50-13,44$ \\
\hline \multirow{2}{*}{20} & \multirow{2}{*}{ Nasiya } & $\underline{7,43(0,02)}$ & $\underline{0,13(0,78)}$ & $\underline{0,089(0,26)}$ & $\underline{1,72(0,47)}$ & $\underline{6,60(0,44)}$ & $\underline{105,88(0,26)}$ & $\underline{4,66(0,23)}$ \\
\hline & & $7,20-7,70$ & $0,09-0,51$ & $0,065-0,146$ & $0,83-2,42$ & $4,61-14,21$ & $64,66-141,59$ & $3,01-5,59$ \\
\hline
\end{tabular}

Note: Above the line - the median, in brackets - the coefficient of variation, below the line - minimum-maximum values. 
Appendix B. The number of species of main groups of zooplankton and the dominant species in 2011-2014 in the tributaries of Lake Ladoga and the Neva river.

\begin{tabular}{|c|c|c|c|c|c|c|}
\hline № & River & $\begin{array}{c}\text { Number of } \\
\text { species }\end{array}$ & Rotifera & $\begin{array}{c}\text { Clado- } \\
\text { cera }\end{array}$ & $\begin{array}{l}\text { Cope- } \\
\text { poda }\end{array}$ & Dominant species \\
\hline 1 & Neva & 45 & 15 & 19 & 11 & $\begin{array}{l}\text { Asplanchna priodonta Gosse, 1850, Euchlanis } \\
\text { lyra Hudson, 1886, Kellicottia longispina } \\
\text { (Kellicott, 1879), Notholca caudata Carlin, } \\
\text { 1943, Bosmina (Bosmina) longirostris (O.F. } \\
\text { Müller, 1785), Bosmina (Eubosmina) } \\
\text { coregoni Baird, 1857, Mesocyclops leuckarti } \\
\text { (Claus, 1857), Eudiaptomus gracilis (Sars, } \\
\text { 1863), Eudiaptomus graciloides (Lilljeborg, } \\
\text { 1888), Eurytemora lacustris (Poppe, 1887) }\end{array}$ \\
\hline 2 & Volkhov & 49 & 15 & 25 & 9 & $\begin{array}{l}\text { K. longispina, Keratella quadrata quadrata } \\
\text { (O.F. Müller, 1786), B. (E.) coregoni, } \\
\text { Daphnia (Daphnia) cristata Sars, 1862, } \\
\text { Disparalona rostrata (Koch, 1841), } \\
\text { Limnosida frontosa Sars, 1862, Scapholeberis } \\
\text { mucronata (O.F. Müller, 1776), M. leuckarti, } \\
\text { Thermocyclops crassus (Fischer, 1853), E. } \\
\text { gracilis, E. graciloides }\end{array}$ \\
\hline 3 & Svir & 45 & 13 & 21 & 11 & $\begin{array}{c}\text { Asplanchna henrietta Langhans, } 1906, A . \\
\text { priodonta, E. lyra, K. longispina, N. caudata, } \\
\text { Acroperus harpae (Baird, 1834), Alonella } \\
\text { nana (Baird, 1850), B. (B.) longirostris, B. } \\
\text { (E.) coregoni, Chydorus sphaericus (O.F. } \\
\text { Müller, 1785), Chydorus ovalis Kurz, } 1875, D \text {. } \\
\text { (D.) cristata, Polyphemus pediculus } \\
\text { (Linnaeus, 1761), E. gracilis, Limnocalanus } \\
\text { macrurus Sars, } 1863\end{array}$ \\
\hline 4 & Syas & 44 & 13 & 26 & 5 & $\begin{array}{c}\text { A. priodonta, Cephalodella auriculata (O. F. } \\
\text { Müller, 1773), Euchlanis dilatata Ehrenberg, } \\
\text { 1832, E. lyra, Synchaeta sp., Alona costata } \\
\text { Sars, 1962, B. (B.) longirostris, B. (E.) } \\
\text { coregoni, C. sphaericus, Ceriodaphnia } \\
\text { quadrangula (O.F. Müller, 1785), Oxyurella } \\
\text { tenuicaudis (Sars, 1862), Pleuroxus truncatus } \\
\text { (O.F. Müller, 1785), Sida crystallina (O.F. } \\
\text { Müller, 1776), Eucyclops macrurus (Sars, } \\
\text { 1863) }\end{array}$ \\
\hline 5 & Burnaya & 51 & 24 & 16 & 11 & $\begin{array}{l}\text { A. henrietta, A. priodonta, Bipalpus hudsoni } \\
\text { (Imhof, } 1891) \text { K. longispina, Synchaeta sp., C. } \\
\text { sphaericus, } B .(\text { E.) coregoni, D. (D.) cristata, } \\
\text { Microcyclops varicans (Sars, 1863), E. } \\
\text { graciloides, E. gracilis }\end{array}$ \\
\hline 6 & Vuoksa & 57 & 20 & 25 & 12 & $\begin{array}{l}\text { Asplanchna herricki Guerne, } 1888, A . \\
\text { priodonta, } \text { K. longispina, } K \text {. q. quadrata, } C . \\
\text { sphaericus, } D . \text {. (D.) cristata, P. truncatus, } E . \\
\text { gracilis, E. graciloides, L. macrurus }\end{array}$ \\
\hline
\end{tabular}




\begin{tabular}{|c|c|c|c|c|c|c|}
\hline № & River & $\begin{array}{c}\text { Number of } \\
\text { species }\end{array}$ & Rotifera & $\begin{array}{c}\text { Clado- } \\
\text { cera }\end{array}$ & $\begin{array}{l}\text { Cope- } \\
\text { poda }\end{array}$ & Dominant species \\
\hline 7 & Pasha & 36 & 8 & 23 & 5 & $\begin{array}{c}\text { Euchlanis incisa Carlin, } 1939, \text { K. longispina, } \\
\text { A. harpae, A. nana, B. (E.) coregoni, C. } \\
\text { ovalis, C. sphaericus, Graptoleberis } \\
\text { testudinaria (Fischer, } 1851), \text { S. mucronata, E. } \\
\text { macrurus } \\
\end{array}$ \\
\hline 8 & Oyat & 39 & 9 & 22 & 8 & $\begin{array}{c}\text { A. priodonta, E. dilatata, B. (B.) longirostris, } \\
\text { B. (E.) coregoni, C. ovalis, C. sphaericus, } P \text {. } \\
\text { truncatus, Thermocyclops oithonoides (Sars, } \\
\text { 1863), Eu.gracilis }\end{array}$ \\
\hline 9 & Yanis & 45 & 7 & 31 & 7 & $\begin{array}{l}\text { Conochilus hippocrepis (Schrank, 1803), } \\
\text { Conochilus unicornis Rousselet, 1892, E. lyra, } \\
\text { K. longispina, A. harpae, B. (B.) longirostris, } \\
\text { B. (E.) coregoni, C. quadrangula, C. } \\
\text { sphaericus, Diaphanosoma brachyurum } \\
\text { (Liévin, 1848), S. mucronata, S. crystallina, } \\
\text { E. macrurus, M. leuckarti }\end{array}$ \\
\hline 10 & Olonka & 43 & 11 & 24 & 8 & $\begin{array}{l}\text { E. dilatata, E. incisa, Synchaeta pectinata } \\
\text { Ehrenberg, } 1832, \text { A. harpae, A. nana, B. (B.) } \\
\text { longirostris, B. (E.) coregoni, C. quadrangula, }, \\
\text { C. ovalis, C. sphaericus, Pleuroxus trigonellus } \\
\text { (O.F. Müller, 1785), P. pediculus, } S . \\
\text { mucronata, M. leuckarti }\end{array}$ \\
\hline 11 & Tulema & 49 & 13 & 26 & 10 & $\begin{array}{c}\text { A. priodonta, B. hudsoni, E. incisa, } K . \\
\text { longispina, A. harpae, A. affinis, Alonella } \\
\text { exigua (Lilljeborg, 1901), A. nana, B. (B.) } \\
\text { longirostris, B. (E.) coregoni, C. sphaericus, } \\
\text { D. brachyurum, D. rostrata, P. pediculus, } \\
\text { Cyclops kolensis Lilljeborg, 1901, M. } \\
\text { leuckarti }\end{array}$ \\
\hline 12 & Tohma & 38 & 13 & 18 & 7 & $\begin{array}{l}\text { A. priodonta, K. longispina, A. harpae, Alona } \\
\text { quadrangularis (O.F. Müller, 1875), B. (B.) } \\
\text { longirostris, B. (E.) coregoni, C. quadrangula, } \\
\text { C. sphaericus, D. rostrata, G. testudinaria, O. } \\
\text { tenuicaudis, Picripleuroxus laevis (Sars, } \\
\text { 1862), S. mucronata, Simocephalus vetulus } \\
\text { (O.F. Müller, 1776), Eucyclops macruroides } \\
\text { (Lilljeborg, 1901), Paracyclops poppei } \\
\text { (Rehberg, 1880) }\end{array}$ \\
\hline 13 & $\begin{array}{c}\text { Kokka- } \\
\text { lan }\end{array}$ & 26 & 10 & 9 & 7 & $\begin{array}{c}\text { Ascomorpha sp., A. priodonta, E. dilatata, } K \text {. } \\
\text { longispina, Keratella quadrata (O.F. Müller, } \\
\text { 1785), Lecane luna luna (O.F. Müller, } 1776), \\
\text { B. (B.) longirostris, B. (E.) coregoni, D. (D.) } \\
\text { cristata, D. brachyurum }\end{array}$ \\
\hline 14 & Vidlitsa & 27 & 11 & 12 & 4 & $\begin{array}{c}\text { Ascomorpha sp., E. lyra, Filinia terminalis } \\
\text { (Plate, 1886), K. longispina, Polyarthra major } \\
\text { Burckhardt, 1900, Trichocerca elongata } \\
\text { (Gosse, 1886), A. harpae, B. (E.) coregoni, C. } \\
\text { sphaericus, T. oithonoides, Cyclops strenuus } \\
\text { Fischer, 1851, Paracyclops fimbriatus } \\
\text { (Fischer, 1853) }\end{array}$ \\
\hline
\end{tabular}




\begin{tabular}{|c|c|c|c|c|c|c|}
\hline № & River & \begin{tabular}{|c|} 
Number of \\
species
\end{tabular} & Rotifera & $\begin{array}{c}\text { Clado- } \\
\text { cera }\end{array}$ & $\begin{array}{l}\text { Cope- } \\
\text { poda }\end{array}$ & Dominant species \\
\hline 15 & Uksun & 40 & 10 & 25 & 5 & $\begin{array}{l}\text { E. lyra K. longispina, Synchaeta sp., A. } \\
\text { harpae, A. exigua, A. nana, B. (B.) } \\
\text { longirostris, B. (E.) coregoni, C. quadrangula, } \\
\text { Chydorus gibbus Sars, 1891, C. sphaericus, } \\
\text { D. rostrata, Eurycercus (Eurycercus) } \\
\text { lamellatus (O.F. Müller, 1776), Monospilus } \\
\text { dispar Sars, 1862, P. pediculus, Eucyclops } \\
\text { serrulatus (Fischer, 1851), T. oithonoides }\end{array}$ \\
\hline 16 & Tuloksa & 46 & 15 & 25 & 6 & $\begin{array}{l}\text { E. lyra, B. hudsoni, Kellicottia bostoniensis } \\
\text { (Rousselet, 1908), S. pectinata, Synchaeta sp., } \\
\text { A. harpae, B. (B.) longirostris, B. (E.) } \\
\text { coregoni, Ceriodaphnia laticaudata P.E. } \\
\text { Müller, 1867, C. sphaericus, Daphnia } \\
\text { (Daphnia) longispina O.F. Müller, } 1785, \text { D. } \\
\text { brachyurum, P. trigonellus, P. pediculus }\end{array}$ \\
\hline 17 & Lava & 29 & 9 & 13 & 7 & $\begin{array}{c}\text { Ascomorpha sp., A. priodonta, K. quadrata, A. } \\
\text { quadrangularis, Alona rectangula Sars, } 1862, \\
\text { B. (E.) coregoni, C. sphaericus, P. pediculus, } \\
\text { S. mucronata, Diacyclops languidus (Sars, } \\
\text { 1863), Macrocyclops albidus (Jurine, 1820), } \\
\text { P. fimbriatus }\end{array}$ \\
\hline 18 & Morje & 41 & 14 & 20 & 7 & $\begin{array}{c}\text { A. priodonta, A. henrietta, E. insica, E. lyra, } \\
\text { Synchaeta sp., A. quadrangularis, A. affinis, } \\
\text { A. nana, B. (B.) longirostris, B. (E.) coregoni, } \\
\text { C.(C.) quadrangula, C. sphaericus, D. (D.) } \\
\text { cristata, D. rostrata, Rhynchotalona falcata } \\
\text { (Sars, } 1862)\end{array}$ \\
\hline 19 & Avloga & 33 & 12 & 16 & 5 & $\begin{array}{c}\text { Brachionus calyciflorus calyciflorus Pallas, } \\
\text { 1776, C. auriculata, Filinia longiseta } \\
\text { (Ehrenberg, 1834), K. longispina, Keratella } \\
\text { cochlearis cochlearis (Gosse, 1851), K. g. } \\
\text { guadrata, B. (E.) coregoni, C. ovalis, D. (D.) } \\
\text { cristata, Daphnia (Daphnia) pulex Leydig, } \\
\text { 1860, Ilyocryptus sordidus (Lievin, 1848), G. } \\
\text { testudinaria, S. vetulus, E. serrulatus, } M . \\
\text { leuckarti }\end{array}$ \\
\hline 20 & Nasiya & 27 & 1 & 21 & 5 & $\begin{array}{l}\text { A. harpae, A. affinis, A. quadrangularis, } B . \\
\text { (E.) coregoni, Ceriodaphnia megops Sars, } \\
\text { 1862, C. sphaericus, D. rostrata, P. pediculus, } \\
\text { S. mucronata, E. macrurus, E. serrulatus, M. } \\
\text { leuckarti, M. varicans }\end{array}$ \\
\hline \multicolumn{2}{|c|}{ Total } & 137 & 56 & 57 & 24 & \\
\hline
\end{tabular}

